\title{
FRUSTRATED INTENTIONS AND BINDING BIOLOGY: SEEKING AID IN THE LAW
}

\author{
ANNE REICHMAN SCHIFF $\dagger$
}

\section{INTRODUCTION}

Lisa, an unmarried woman, is impregnated through the process of artificial insemination by donor (AID) with sperm donated by Andrew, an acquaintance. Lisa and Andrew agree before the insermination that Andrew will have no support obligations towards the child and that he will not seek custody or visitation rights. However, during the course of Lisa's pregnancy or following the birth of the child, one of the following two scenarios occurs:

(i) Andrew changes his mind with regard to the original agreement and brings an action to obtain visitation rights; or

(ii) Lisa changes her mind with regard to the original agreement and brings an action seeking support payments from Andrew.

Should Andrew's biological tie be a sufficient basis for him to be granted visitation rights over Lisa's strenuous objections?

$\dagger$ Assistant Professor of Law, University of Pittsburgh School of Law. B.A., Monash University (Australia), 1978; LL.B., Monash Law School (Australia), 1981; LL.M., Yale Law School, 1986. I am deeply grateful to my colleagues Jody Armour, Ruth Colker, Margaret Mahoney, and Welsh White for their thoughtful comments and suggestions on prior drafts of this Article. My special thanks to Jay Katz, who not only gave valuable guidance with respect to this Article, but whose remarkable insights and wisdom have enriched immeasurably my own thinking in the new reproductive practices area, and in law and medicine generally. I would also like to thank Adrienne Asch for her helpful comments, and for the many stimulating conversations we had concerning artificial insemination and other new reproductive practices. Credit for diligent research assistance goes to Lisa Ventresca, Cheryl Forino, and Christopher Cahillane. I wish to thank the University of Pittsburgh School of Law for giving me the opportunity to present an earlier version of this Article at a colloquium, and for supporting this project through a summer research stipend. Finally, I would like to express my profound appreciation to my husband, Danny Schiff, who has accompanied me intellectually and sustained me emotionally throughout this journey. 
Should Andrew's biological connection to the child allow Lisa to extract support obligations from him against his will? Should the parties' pre-conception intentions shape the way the law treats their responsibilities to the child?

The establishment of a legal framework to determine the assignment of parental rights and responsibilities in the context of AID $^{1}$ compels an examination of fundamental issues concerning parenthood, procreation, and family. Yet the relationship of these issues to AID has rarely been articulated, let alone explored. Whatever the reasons for the silence that historically has surrounded AID, it is important that hitherto unchallenged assumptions about the role of biology and intent be made explicit and be examined. Only then will it be possible to formulate sound law and policy that anticipate and deal adequately with potential legal problems.

If the law governing AID is to be responsive to current social realities, a variety of interests needs to be addressed. These include the interest of individuals in having their decisions regarding procreation respected, the interest of the child in being raised im a committed, nurturing relationship, and the interest of the state in promoting family units that conform to a social norm or cultural ideal.

Current law concerning AID largely discounts the pre-conception intentions of the parties. ${ }^{2}$ Instead, it treats the parties as though they had achieved conception through sexual intercourse, assigning legal parental status in such a way as to reinforce the traditional nuclear family model. In so doing the law disregards the fact that AID is used not only by married couples for medical reasons, ${ }^{3}$ but also by individuals and couples who intend to create

1. Artificial insemination (AI) is a technique involving the insertion of semen into a woman's cervical canal or directly into her uterus by means other than sexual intercourse. When the source of the semen is the woman's husband, the procedure is referred to as artificial insemination by husband $(\mathrm{AIH})$. When the source of the semen is a man other than the woman's husband, the procedure is called artificial insemination by donor (AID). AI is an extremely "low-tech" procedure, usually requiring only a syringe or even a utensil as basic as a turkey-baster. Daniel Wikler \& Norma J. Wikler, Turkey-Baster Babies: The Demedicalization of Artificial Insemination, 69 MILBANK Q. 5, 8 (1991).

2. See infra subsection $\mathrm{I}(\mathrm{B})(2)$.

3. Medical reasons motivating the use of AID include lack of sperm production, $R h$ incompatibility, the risk of passing on a known genetic disorder or sexually transmitted disease, and the risk resulting from exposure to mutagens. See generally U.S. CONGRESS, OfFice of TEChNology AsSessment, INFERTILTTY: MEdical AND SOCIAL Choices 
familial arrangements that do not necessarily conform to this model. Indeed, it is precisely because AID separates reproduction from sexuality that it affords single women and lesbian couples the opportunity to form "non-traditional" family units, without the need for sexual involvement. AID, therefore, has far-reaching societal consequences, for it greatly augments the range of available personal and social options in procreation. ${ }^{4}$ Yet the law has not kept pace with the new advances in this field, and it continues to mipose a social norm that is often at variance with the desires and intentions of the parties imvolved.

AID and other new reproductive practices ${ }^{5}$ have a profound impact on our understanding of the concept of "parenthood." Parenthood can now be fragmented into distinct components of a social, genetic, or, in the case of surrogate motherhood, gestational nature, resulting in a possible multiplicity of "reproductive collaborators," as they are sometimes termed. ${ }^{6}$ One of the unforeseen outcomes of new reproductive practices is that the conventional termmology for describing these inultiple "collaborators" and their respective legal roles has been rendered inadequate. With respect to procreation by sexual intercourse, the law has designated a maximum of two persons-one of each sex-as having "legal parental status."7 Even in this context, the usefulness of such a portrayal may be limited, given the large percentage of families that do not conform to the nuclear family model; ${ }^{8}$ in the context of

61-82 (1988) (discussing factors contributing to infertility) [hereinafter OTA INFERTILITY REPORT].

4. See Barbara Kritchevsky, The Unmarried Woman's Right to Artificial Insemination: A Call for an Expanded Definition of Family, 4 HARV. WOMEN's L.J. 1 (1981) (arguing that AID should be widely available to unmarried women); Note, Reproductive Technology and the Procreation Rights of the Unmarried, 98 HARV. L. REv. 669 (1985) (arguing that legislatures and courts cannot constitutionally limit access to AID).

5. Other new reproductive practices include in vitro fertilization, embryo transfer, gamete intrafallopian transfer, embryo freezing, surrogate motherhood, and egg donation. See OTA INFERTILITY REPORT, supra note 3, at 239-308.

6. The term "collaborative reproduction" is used by some writers to refer to the provision of gametes or gestation in a reproductive arrangement. See, e.g., JOHN A. ROBERTSON, CHILDREN OF CHOICE: FREEdOM AND tHE NEW REPRODUCTIVE TECHNOLOGIES 119 (1994).

7. The term "legal parental status" refers to a bundle of rights and obligations, of which the most significant relate to custody, visitation, support, and inheritance. Other rights and duties include the areas of education, religious upbringing, discipline, and medical treatment. Katharine T. Bartlett, Rethinking Parenthood as an Exclusive Status: The Need for Legal Alternatives When the Premise of the Nuclear Family Has Failed, 70 VA. L. REV. 879, 884-85 (1984).

8. Courts traditionally have adopted a formal approach to defining "family," recog. 
new reproductive practices, it is far too restrictive and insufficiently descriptive. ${ }^{9}$

The main thesis of this Article is that, in contrast to procreation by sexual intercourse, artificial insemination requires a legal response predicated on enforcing the pre-conception intentions of the parties. ${ }^{10}$ Whereas reproduction may or may not be the intended aim of sexual intercourse, a pregnancy achieved through artificial insemination is unambiguously intentional, purposeful, and deliberate. Parties contemplating reproduction through AID are in a position to negotiate, prior to conception, the allocation of parental rights and obligations, and they usually enter the AID arrangement in reliance on such an agreement. It is in the interests of both parties, as well as the resulting child, that these relied-on expectations be respected by the courts in the event of a later dispute.

This Article examines the current allocation of parental rights and responsibilities in AID and proposes an alternative model that emphasizes the pre-conception intentions of the parties. Part I describes current statutes and caselaw governing parental status in the context of procreation both through sexual intercourse and by means of AID, and highlights the problems that exist when parental rights conflicts arise between unmarried women and known donors. Part II discusses the reasons why the approach offered by current family law principles is inappropriate in the context of new

nizing only those relationships based on biology, adoption, or marriage. However, some commentators have urged that a functional approach to family be applied, by inquiring as to whether "a relationship shares the essential characteristics of a traditionally accepted relationship and fulfills the same human needs." Note, Looking for a Family Resemblance: The Limits of the Functional Approach to the Legal Definition of Family, 104 HARV. L. REV. 1640, 1646 (1991); see also Bartlett, supra note 7, at 882.

9. To minimize confusion, the phrases "legal parental status" and "legal parenthood" (and variations such as "legal parent" and "legal father") are used in this Article to describe the legal status occupied either by the custodial parent or by a noncustodial parent who has agreed prior to conception to have significant ongoing involvement with and responsibility for a child. Thus, for present purposes-and contrary to current law-a sperm donor who has agreed to minimal or no rights or obligations with respect to a child would not be eligible to be described as a "legal parent," even though he is a biological parent.

Consideration might be given to expanding the terminology used in this context and applying a more functional definition. For example, the parental roles could be designated as "primary" and "secondary," depending on the functions performed by the persons occupying those roles.

10. See infra Part II. 
reproductive practices. It proposes an intent-based system in which pre-conception intentions would be enforced, thereby ensuring the predictability of legal outcome and minimizing the potential for conflicts between the adult parties. As the existence and content of the original agreement must be clearly evidenced so that preconception intentions can be enforced, this Article proposes a registration scheme whereby parties who wish to be assured of a predictable legal outcome may register their agreement with the state before the insemination takes place. Part III argues that even under an intent-based system, the significance of biology should be acknowledged as having potentially profound societal and personal implications. Consequently, it maintains that, as law and public policy with respect to AID develop, some fundamental assumptions concerning the desirability of anonymity need to be reexamined as law and public policy with respect to AID develop.

\section{The Determination of Legal Parenthood: CURRENT LAW}

In determining legal parental status, the question of the relative weight to be accorded biology and intent as separate components of parenthood needs to be considered. Specifically, how much significance does biology carry under present law when the biological act of procreation is unaccompanied by an intent to raise the child?

\section{A. Legal Parental Status and Procreation Through Sexual Intercourse}

In a nuinber of areas of law, such as contract, tort, and criminal law, the mental state of an individual is critical in determining legal consequences. ${ }^{11}$ Under current family law principles, however, intent is relatively unimportant in the determination of legal parental status. Biology is accorded far more weight than intent, the amount of weight depending largely on the social policy goal being promoted.

11. In criminal law, a "guilty mind" (mens rea), as well as a "guilty act" (actus rets), is required for most crimes. In contract law, there must be a "meeting of the minds" (consensus ad idem) before courts recognize and enforce a contractual obligation. With the exception of strict liability, torts are defined and categorized according to the mental state of the defendant: intention, recklessness, or negligence. 
The law traditionally has placed a high value on the biological component of parenthood, ${ }^{12}$ reflecting in part the significance that biological connection represents to many people. Indeed, the pain of infertility is itself testimony to the importance placed on the presence of a genetic link..$^{13}$ So, too, one of the reasons why AID is frequently viewed as a more attractive option than adoption is that with AID one of the rearing parents will be genetically related to the resulting child. For some individuals and couples, the wish to pass on genes to future generations is a profound yearning that gives meaning to parenthood. For other couples, the desire to have a child "of one's own" has to do not only with the transmission of genes but also with deep longings to fuse their two genetic heritages and thereby create a "new branch of their joined family tree."14

In the case of fatherhood, however, biology, while traditionally the primary determinant of legal paternal status, has not been the only means of establishing paternity. Unlike biological motherhood, which was an objectively ascertainable fact, ${ }^{15}$ biological fatherhood was, until the development of scientific tests to deter-

12. See Developments in the Law-Medical Technology and the Law, 103 HARV. L. REV. 1519, 1527 (1990) (commenting that "[j]udges have repeatedly responded to parental disputes by choosing solutions that implicitly favor biological over social relationships," and that "legislatures have created incentives skewed toward biological parenthood and against adoption"); Andrea E. Stumpf, Redefining Mother: A Legal Matrix for New Reproductive Technologies, 96 YALE L.J. 187, 195 n.29 (1986).

13. It might be claimed, however, that for some the pain of infertility has less to do with not having a biological child than with not having a child to raise, regardless of the presence or absence of a biological connection. For a poignant description of one person's struggle with the personal, medical, and social aspects of infertility, see N.J. COMM'N ON LEGAL \& ETHICAL PROBLEMS IN THE DELIVERY OF HEALTH CARE, AFTER Baby M: The Legal, Ethical and Social Dimensions of Surrogacy 13 (1992) [hereinafter N.J. COMM'N REPORT].

14. LEON R. Kass, TOWARD a MORE NATURAL Science 111 (1985). Kass states,

[F]or most of us, it would not be a matter of indifference if the sperm used to fertilize the egg were provided by an identical twin brother. ... Rather, the humanly crucial sense of one's own, the sense that leads most people to choose their own, rather than to adopt, is captured by such phrases as "my seed," "flesh of my flesh," "sprung from my loins." More accurately, since one's own is not the own of one but of two, the desire to have a child of one's own is a couple's desire to embody, out of the conjugal union of their separate bodies, a child who is flesh of their separate flesh made one.

Id. at 110 .

15. The ability of new reproductive practices to separate the genetic and gestational components of motherhood by means of egg donation and surrogate motherhood means that the biological "fact" of motherhood is no longer self-evident. See Johnson v. Calvert, 851 P.2d 776, 780-81 (Cal.), cert. denied, 114 S. Ct. 206 (1993). 
mine paternity, "a matter of inference rather than certainty." For this reason, the common law estabhished that a claim to fatherhood also exists if the male and the mother of the child are married to each other. ${ }^{17}$ Thus, the common law presumption of legitimacy in marriage, whereby any child born to a married couple is irrebuttably presumed to be the legitimate child of the marriage regardless of biological evidence to the contrary, ${ }^{18}$ serves to resolve the problem of paternal uncertainty by replacing the requirement of a biological tie to the child with the requirement of a marital tie to the child's mother.

Historically, the purposes of the irrebuttable presumption of legitimacy were to protect public expenditure by preventing the child from becouming dependent on state benefits, to promote the societal norm of a traditional family unit, and to shield the child from the social and economic hardships resulting from illegitimacy. ${ }^{19}$ Today, though the social stigma of illegitimacy is considerably diminished, the law still favors legitimating the child, even when there is biological evidence to the contrary. ${ }^{20}$

16. Marjorie M. Schultz, Reproductive Technology and Intent-Based Parenthood: An Opportunity for Gender Neutrality, 1990 WIS. L. REV. 297, 316.

17. See In re Findlay, 170 N.E. 471,473 (N.Y. 1930). Yet a third basis for a claim to fatherhood is adoption, following the termination of the biological parents' parental rights. However, while adoption is an important means for acquiring parental status, it is a statutory creation that was completely unknown at common law.

18. "If a husband, not physically incapable, was within the four seas of England during the period of gestation, the court would not listen to evidence casting doubt on his paternity." Id. at 472 . Moreover, under what became enshrined as Lord Mansfield's Rule, neither husband nor wife was allowed to give evidence of lack of sexual intercourse. The origins of this principle are found in the case of Goodright v. Moss, 98 Eng. Rep. 1257, 1258 (K.B. 1777), in which Lord Mansfield stated, "But it is a rule, founded in decency, morality, and policy, that [the spouses] shall not be permitted to say after marriage, that they have had no connection, and therefore that the offspring is spurious."

19. See generally Carol Smart, "There is of course the distinction dictated by nature": Law and the Problem of Paternity, in Reproductive TeCHNOLOGIEs 98-117 (Michelle Stanworth ed., 1987) (tracing the law's attachment of men to children).

20. Under statutory law, the presumption of legitimacy is irrebuttable in some states. Even in many states where the presumption is rebuttable, only the husband or wife-not the putative father alone-may challenge the presumption. For example, in Michael H. v. Gerald D., 491 U.S. 110 (1989), the U.S. Supreme Court held, based on the relevant California statutory provision, that the presumption of legitimacy could be rebutted only by the husband or wife, and then only in very limited circumstances. Although blood tests established a $98.07 \%$ probability that the putative father was the biological father of the child, the Court held that the presumption of legitimacy applied and that it did not infringe on the due process rights of the putative father. Id. at 114, 124-25. 
When the biological parents of a child are unmarried, there is no legal presumption to rely on and, therefore, the biological paternal tie is accorded greater significance by the law. However, even though the biological connection is a sufficient condition for the imposition of legal obligations-especially support obligations-on the father, it is not in and of itself a basis for according the unwed father legal rights with respect to the child. To achieve this, the unwed father needs to demonstrate not only a biological link but also a commitment to establishing a social relationship with the child. ${ }^{21}$ The U.S. Supreme Court in Lehr v. Robertson ${ }^{22}$ observed that there is a "clear distinction between a mere biological relationship and an actual relationship of parental responsibility, ${ }^{, 23}$ and stated,

The significance of the biological connection is that it offers the natural father an opportunity that no other male possesses to develop a relationship with his offspring. If he grasps that opportunity and accepts some measure of responsibility for the child's future, he may enjoy the blessings of the parent-child relationship and make uniquely valuable contributions to the child's development. ${ }^{24}$

Therefore, it is only if the unmarried biological father "grasps that opportunity" that he and the mother are regarded as being on an

21. The constitutional rights of an unwed biological father have been considered by the U.S. Supreme Court in Lehr v. Robertson, 463 U.S. 248 (1983) (involving due process and equal protection claim regarding unwed father's right to have notice of adoption hearings and right to be heard prior to adoption of child by mother's husband); Caban v. Mohammed, 441 U.S. 380 (1979) (challenging as a violation of equal protection a New York statute that allowed an unwed mother, but not an unwed father, to veto an adoption by withholding consent); Quilloin v. Walcott, 434 U.S. 246 (1978) (involving due process and equal protection claims by unwed biological father seeking to block adoption of child by mother's husbaud); and Stanley v. Illinois, 405 U.S. 645 (1972) (challenging an Illinois statute that conclusively presumed every unwed father to be unfit to care for his children).

22. 463 U.S. at 248.

23. Id. at $259-60$.

24. Id. at 262 . 
equal footing vis-à-vis the child. ${ }^{25}$ Otherwise, while he has support obligations, he is not able to seek custody or visitation rights. ${ }^{26}$

Thus, the common law presumption of legitimacy and the law with respect to unwed fathers' rights demonstrate that the existence of a biological relationship is not necessarily conclusive in determining parental rights. In the case of the marital presumption of legitimacy, the absence of a biological connection does not deprive the husband of such rights and, in the case of the unwed father, its presence does not automatically guarantee them. Rather, the weight that the law accords to biology is influenced heavily by favored social policies, such as the desirability of the nuclear family and the importance to the child of having nurturing, committed parents.

The current exceptions to biology as the determinant of legal parental status do not include contractual agreements between the parties whereby they negotiate their legal rights and obligations. ${ }^{27}$

25. It is unclear whether the law requires a proven track record of a committed relationship with the child or whether a stated desire to establish such a relationship is sufficient. In each of the cases considered to date by the U.S. Supreme Court as to the unwed father's constitutional rights, see supra note 21 , an opportunity existed over a period of time for the father to develop a parental relationship with the child. See, e.g., Stanley, 405 U.S. at 646. However, in AID cases there is often no such opportunity, because the dispute between the unwed parents arises when the child is a newborn or shortly thereafter. The question of the unmarried father's constitutional rights at the time of the birth of his child has never been addressed directly by the Supreme Court. MARTHA A. Field, SURROGATE MOTHERHOOD 121-25 (1990).

26. Depending on the court's assessment as to whether maintaining contact with the biological father is in the child's interests, the court may award visitation rights. Should the biological father seek custody, the court would apply the "best interests of the child" test, a comparative standard that attempts to judge the respective parenting abilities of the biological parents. This test, however, while somewhat problematic in general, is particularly so in the AID context because in most cases the child is a newborn at the time of litigation. Therefore, there is no parenting history-or at least, not with respect to the particular child-upon which comparative assessments can be made. An analysis of some of the problems posed by the best interests standard in custody disputes following the dissolution of marriage is found in Robert H. Mnookin, Child-Custody Adjudication: Judicial Functions in the Face of Indeterminacy, LAW \& CONTEMP. PROBS., Summer 1975, at 226, 236. For a discussion of the applicability of the best interests test in the context of a different new reproductive practice, surrogate motherhood, see N.J. COMM'N REPORT, supra note 13 , at $144-53$.

27. E.g., Estes v. Albers, 504 N.W.2d 607 (S.D. 1993). In this case, Albers consented to father a child for Estes after the two agreed that Albers would have no financial responsibility for the child. The child was conceived through sexual intercourse, and Albers acknowledged his paternity. Id. at 608. Later he agreed to support the child, and Estes sued for increased support. Id. The Supreme Court of South Dakota rejected Albers's argument that his status was nothing more than that of a semen donor and that he 
The state in its role as parens patriae has an interest in protecting children by designating those who are responsible for children's care and custody. In general, those so designated by the law are the biological parents. When the biological parents are unwilling or unable to care for the child, or when it becomes apparent that the child requires protection from the biological parents, the state intervenes by providing for the termination of parental rights and the transfer of custody and control of the child by means of adoption or placement in a foster home. The legal rules relating to adoption and the termination of parental rights, as well as the prohibition against "baby selling," ensure that the acquisition or transfer of parental rights does not take place by contractual agreements between private parties. The state thereby seeks to promote the child's interest in stability and security by clearly identifying from the outset those responsible for the welfare of the child, without the risk of disputes regarding the interpretation of contractual terms. ${ }^{28}$

\section{B. Legal Parental Status and AID}

Despite the fact that AID is the oldest of the "new" reproductive techniques, ${ }^{29}$ there is comparatively little statutory law or

should thus be afforded the protection given by the law to anonymous donors. The court held that since the agreement was not supported by adequate consideration and was not court-approved, as required by the state statute, it was void. Id. at 609 . The court noted that "[t]his result is consistent with the public policy that parental agreements which have the effect of making a child a public charge cannot be countenanced and a support agreement injurious to the best interest of the child is invalid for any purpose." Id.

28. A.M. Capron \& M.J. Radin, Choosing Family Law over Contract Law as a Paradigm for Surrogate Motherhood, 16 LAw, MED. \& Health CARE 34, 35 (1988).

29. The first reported case of AID in the United States was an infamous one. It took place in 1884, at Jefferson Medical College in Philadelphia, where Dr. William Pancoast inseminated his patient, a married woman, with the semen of one of his medical students by means of a syringe. The woman, who had been anesthetized with chloroform during the procedure, had no knowledge that she was being inseminated with donor sperm. She was never informed of this fact, even after the birth of her son nine months later. GeNA COREA, THE Mother MACHINE 12 (1985).

Later interest in AID was generated largely as a result of the enthusiasm and pioneering work of Dr. Robert L. Dickinson, who began performing the procedure in the 1890s. The practice began to gain momentum in the medical profession in the 1920 s and 1930s. Wilfred J. FinEGold, ARTIFICIAL INSEMination 7 (2d ed. 1976).

While the silence and stigma that historically have surrounded AID and the subject of male infertility preclude reliable estimates of the total number of children born through AID, a survey conducted by the Office of Technology Assessment (OTA) estimated that in 1986-1987, 172,000 women underwent artificial insemination, resulting in a 
caselaw on the subject. Present law concerning AID tends to be piecemeal, failing to provide a coherent response to the complexities and challenges presented by this not-so-"new" reproductive practice. $^{30}$

1. Current Statutory Law. Existing AID legislation varies from state to state. Fifteen states have no statute addressing parental rights and responsibilities with respect to AID. Of the thirty-five states that have legislated on this matter, ${ }^{31}$ thirteen modeled their statutes on the Uniform Parentage Act (UPA), ${ }^{32}$ an advisory statute developed in 1973 by the National Conference of Commissioners on Uniform State Laws. Each state can choose either to accept the UPA model as is, to adopt a variant of it, to enact legislation based on a different model, or to make no statutory pronouncement at all. Where no state statute exists, or where the circumstances of a case fall outside the criteria estab-

total of 65,000 births. Of these, 35,000 births were the result of artificial insemination by husband (AIH), and 30,000 resulted from AID. U.S. CONGRESS, OFFICE OF TECHNOLOgY AsSessment, ARTIFicial INSEMINATION: PRACTICE IN THE UNITED STATES: SUMMARY OF A 1987 SURVEY: BACKGROUND PAPER 3 (1988) [hereinafter ARTIFICIAL INSEMINATION REPORT].

30. One writer describes the current environment within which AID operates as follows: "The present system is characterized by the absence of legal control, no comprehensive code of practice, no systematic counseling, problems of illegality, concealment, deception, secrecy, as well as tacit official and medical acceptance." ELIZABETH NOBLE, HAVING YOUR BABY BY DONOR INSEMINATION 240-41 (1987).

31. See Ala. CODE § 26-17-21 (1992); ALASKA STAT. § 25-20-045 (1991); ARIz. REv. STAT. ANN. \& 12-2451(B) (1994); ARK. CODE ANN. \& 9-10-201 (Michie 1993); CAL. Civ. CODE $\S 7005$ (West 1983); Colo. Rev. Stat. $\$ 19-4-106$ (Supp. 1993); ConN. GEN. STAT. §§ 45a-771 to -775 (1992); FLA. STAT. ANN. \& 742.11 (West Supp. 1994); GA. CODE ANN. \$§ 19-7-21, 43-34-42 (1991); IDAHO CODE $\$ \S 39-5401$ to -5408 (1993); ILl. ANN. STAT. ch. 750, para. 40/3 (Smith-Hurd 1993); KAN. STAT. ANN. §§ 23-128 to -130 (1988); LA. CIV. CODE ANN. art. 188 (West 1993); MD. CODE ANN., EST. \& TRUSTS § 1-206(b) (1991); Mass ANN. Laws ch. 46, § 4B (Law. Co-op. 1993); MiCh. COMP. LAWS § 333.2824(6) (1992); MINN. STAT. § 257.56 (1993); MO. ANN. STAT. $\S 210.824$ (Vernon Supp. 1994); MONT. CODE ANN. § 40-6-106 (1993); NEV. REV. STAT. ANN. § 126.061 (Michie 1993); N.H. REv. STAT. ANN. § 168-B:3(e) (1994); N.J. STAT. § 9:17-44 (1993); N.M. STAT. ANN. \& 40-11-6 (Michie 1994); N.Y. DoM. REL. LAW § 73 (McKinney 1988); N.C. GEN. STAT. § 49A-1 (1984); N.D. CENT. CODE § 14-18-03 (1991); OHIO REv. CODE ANN. \$§ 3111.30-38 (Baldwin 1992); OKLA. STAT. tit. 10, $\S \S 551-553$ (1994); OR. REV. STAT. $\$ \S 109.239, .243$ (1990); id. $\$ \S 677.355, .360, .365$, 370 (1989); TENN. CODE ANN. § 68-3-306 (1992); TEX. FAM. CODE ANN. § 12.03 (West 1986 \& Supp. 1994); VA. CODE ANN. $\S \S 20-156$ to -165 (Michie 1994); WASH. REV. CODE § 26.26.050 (1994); WIS. STAT. \& 891.40 (1993); WYO. STAT. \& 14-2-103 (1994).

32. UNIF. PARENTAGE ACT, 9B U.L.A. 287 (1987). The 13 states that have modeled their legislation on the UPA are Alabama, California, Colorado, Illinois, Minnesota, Missouri, Montana, Nevada, New Jersey, New Mexico, Washington, Wisconsin, and Wyoming. 
lished by statute, any dispute concerning parental rights and responsibilities in an AID case is governed by traditional family law principles.

The purpose of the UPA is to ensure that children born out of wedlock are not disadvantaged by the status and stigma of illegitimacy. ${ }^{33}$ Under section 5 of the UPA ${ }^{34}$ the only provision dealing with AID, the establishment of a legal relationship between the child born through AID and the husband of the woman undergoing AID is based on the fulfillment of three conditions: that the woman undergoing AID be married, that her husband consent to the AID procedure, and that the AID procedure be carried out under the supervision of a hicensed physician. The UPA thus employs an "inducement" model, whereby the law attempts to channel social behavior by providing the inducement of a predictable legal outcome. ${ }^{35}$ If the conditions specified in the UPA are met, the woman's husband is "treated in law as if he were the natural father" of the child. ${ }^{36}$ A legal paternal relationship is thus created despite the fact that there is no biological relationship between the woman's husband and the child, and despite the fact that there has been no legal adoption of the child by the woman's husband. ${ }^{37}$ Section 5 further provides that where

33. The Prefatory Note to the UPA states that the purpose of the Act is to provide "substantive legal equality [for] all children regardless of the marital status of their parents." Id. at 288 Prefatory Note. Thus, the UPA focuses on the establishment of a parent-child relationship and explicitly states that this relationship is not dependent on whether the child's parents are married.

34. Section 5 provides:

(a) If, under the supervision of a licensed physician and with the consent of her husband, a wife is inseminated artificially with semen donated by a man not her husband, the husband is treated in law as if he were the natural father of a child thereby conceived. The husband's consent must be in writing and signed by him and his wife. The physician shall certify their signatures and the date of the insemination, and file the husband's consent with the [State Department of Health], where it shall be kept confidential and in a sealed file. However, the physician's failure to do so does not affect the father and child relationship. All papers and records pertaining to the insemination, whether part of the permanent record of a court or of a file held by the supervising physician or elsewhere, are subject to inspection only upon the order of the court for good cause shown.

(b) The donor of semen provided to a licensed physician for use in artificial insemination of a married woman other than the donor's wife is treated in law as if he were not the natural father of a child thereby conceived.

Id. at 301.

35. For a description of the inducement model and other models of state policy, see OTA INFERTILITY REPORT, supra note 3, at 285-88.

36. UNIF. PARENTAGe ACT § 5(a), 9B U.L.A. at 301.

37. The same result was reached in a number of cases that arose prior to the enact- 
a legal relationship between the woman's husband and the child has been created by this section, all legal ties between the donor and the child are severed. ${ }^{38}$ Despite his biological connection to the child, the donor is "treated in law as if he were not the natural father" of the child. ${ }^{39}$ Some UPA-based statutes sever the legal relationship between the donor and the child not only when the woman is married, but also when she is single. ${ }^{40}$ In these jurisdictions, a child born through AID has no legal father.

There are currently twenty-two state statutes dealing with AID that are not modeled on the UPA. ${ }^{41}$ Like the UPA, these statutes share the aim of declaring legitimate a child born of AID to a husband and wife when the husband has given his consent. ${ }^{42}$ A range of approaches is evident among these statutes concerning a number of issues, such as the marital status of the woman undergoing $\mathrm{AID},{ }^{43}$ the involvement of physicians in the AID proce-

ment of any AID legislation. In People v. Sorensen, 437 P.2d 495 (Cal. 1968), the Supreme Court of California held that a husband who consented to his wife being artificially inseminated with donor sperm had a legal obligation to support the child, since "it is safe to assume that without defendant's active participation and consent the child would not have been procreated." Id. at 499 . Although the court's holding was limited to the issue of the husband's criminal liability for nonsupport, the court stated that the public policy of California favors legitimation and that "no valid public purpose is served by stigmatizing an artificially conceived child as illegitimate." $I d$. at 501 . The question of legitimacy was considered also in the New York case of $I n$ re Adoption of Anonymous, 345 N.Y.S.2d 430 (Sur. Ct. 1973), in which the court concluded that "a child born of consensual AID during a valid marriage is a legitimate child entitled to the rights and privileges of a naturally conceived child of the same marriage." Id. at 435-36. Cf. Gursky v. Gursky, 242 N.Y.S.2d 406, 406 (Sup. Ct. 1963) (holding that "a child conceived by means of artificial insemination of the wife through the use, with the husband's consent, of semen contributed by a donor other than the husband was not the legitimate issue of the husband, but that the husband was liable for support of the child").

38. See UNIF. PARENTAGe ACT § 5(b), 9B U.L.A. at 301.

39. Id.

40. In California, Colorado, Illinois, New Jersey, New Mexico, Ohio, Washington, Wisconsin, and Wyoming, the word "married" is omitted in the statutory equivalents to $\S 5(b)$ of the UPA.

41. The states with such statutes are Alaska, Arizona, Arkansas, Connecticut, Florida, Georgia, Idaho, Kansas, Louisiana, Maryland, Massachusetts, Michigan, New Hampshire, New York, North Carolina, North Dakota, Ohio, Oklahoma, Oregon, Tennessee, Texas, and Virginia.

42. In most of these statutes, the child is "deemed" or "presumed" to be, or "considered" or "treated" as, the natural, legitimate child of the husband and wife. The Florida and Georgia statutes create an irrebuttable presumption of legitimacy. See FLA. STAT. ANN. \& 742.11 (West Supp. 1994); GA. CODE ANN. § 19-7-21 (1991). Arizona takes a more restrictive approach than the other states, providing only for "duties of support" rather than for legitimation. See ARIZ. REV. STAT. ANN. § 12-2451(B) (1994).

43. The use of AID by unmarried women is neither expressly precluded nor ap- 
dure, ${ }^{44}$ and whether the donor's legal relationship to the child is severed. ${ }^{45}$

The existing statutes, both UPA-based and non-UPA-based, suffer from underinclusiveness. As the range of situations covered is extremely narrow, current legislation fails to resolve comprehensively the many complexities involved in assigning parental status in AID cases. ${ }^{46}$ If the procedure is performed without the super-

proved by the majority of the statutes. However, in Connecticut, Kansas, and Oklahoma, the legislation clearly limits AID to married women. CONN. GEN. STAT. \& 45a-771 (1992); KAN. STAT. ANN. § 23-128 (1988); OKLA. STAT. tit. 10, § 551 (1994). By contrast, in New Hampshire and Ohio, the use of AID by unmarried women is explicitly contemplated. N.H. REV. STAT. ANN. § 168-B:3(e) (1994); OHIO REV. CODE ANN. § 3111.31 (Baldwin 1992).

44. Performance or supervision of the AID procedure by a physician is required in Alaska and New York, if the child is to be considered the legitimate child of the husband and wife. ALASKA STAT. $\S 25-20-045$ (1991); N.Y. DOM. REL. LAW $\S 73$ (McKinney 1988). In slightly less than half of the statutes there is no mention of physician involvement in the section conferring legitimacy; see, for example, the statutes of Arkansas, Connecticut, Florida, Idaho, Kansas, Louisiana, Maryland, Massachusetts, Michigan, North Carolina, Olio, Oklahoma, Oregon, Tennessee, and Texas. However, in a number of states, artificial insemination may be carried out only by persons licensed to practice medicine or persons who are under the supervision and control of a physician. ARK. CODE ANN. § 9-10-201 (Michie 1993); CONN. GEN. STAT. § 45a-771 (1992); GA. CODE ANN. \& 43-34-42 (1991); IDAHO CODE \& 39-5402 (1993); OHIO REV. CODE ANN. $\S 3111.32$ (Baldwin 1992); OKLA. STAT. tit. 10, § 551 (1994). In Georgia, the performance of AID by anyone not authorized to practice medicine is a felony punishable by imprisonment for a term of one to five years, GA. CODE ANN. § 43-34-42, and in Idalo it is a misdemeanor, IDAHO CODE § 39-5407. Where the statute does not explicitly require physician involvement in the section conferring legitimacy but provides elsewhere that AID may be performed only by a physician, a question arises as to the legitimacy of a child born to a married couple when the AID procedure was not performed by a physician. See McIntyre v. Crouch, 780 P.2d 239, 243 (Or. Ct. App. 1989) (holding that under the relevant state legislation, the legitimacy of the child was not affected by the fact that AID had been performed without a plysician), cert. denied, 495 U.S. 905 (1990).

45. Only six non-UPA-based statutes-those in Connecticut, Idaho, Ohio, Oregon, Texas, and Virginia-contain a provision severing the donor's legal relationship to the child. ConN. Gen STAT. § 45a-771 (1992); IDAHo CODE § 39-5405 (1993); OHIO REV. CODE ANN. § 3111.37 (Baldwin 1992); OR. REV. STAT. \& 109.239 (1990); TEX. FAM. CODE ANN. § 12.03 (West 1986 \& Supp. 1994); VA. CODE ANN. § 20-158 (Michie 1994). The remainder of the statutes are silent as to the donor's legal status. New Hampshire's legislation provides that when an unmarried woman is inseminated with the semen of an unmarried donor, they may agree in writing in advance of the procedure that the donor will be the legal father. N.H. REV. STAT. ANN. $\S 168-B: 3(e)$ (1994).

46. The skeletal nature of the UPA provision dealing with AI is acknowledged in the comment to $\S 5$. The comment states that the "Act does not deal with many complex and serious legal problems raised by the practice of artificial insemination" and notes that "[f]urther consideration of other legal aspects of artificial insemination has been urged on the National Conference of Commissioners on Uniform State Laws and is recommended to state legislators." UNIF. PARENTAGE ACT $\S 5 \mathrm{cmt}$., 9B U.L.A. at 302 
vision of a physician, ${ }^{47}$ or if the woman's husband has not consented to the procedure, or-in most states-if the woman is unmarried, ${ }^{48}$ AID participants do not receive the protection offered by the UPA-based statutes. Similarly, no legislative guidance is offered concerning the legal outcome in a situation falling outside that described $\mathrm{m}$ the non-UPA-based statutes. Given that in the absence of any statutory protection, traditional family law principles are applied, the legal outcome as to the assignment of parental status may contradict and frustrate the original intentions of the AID participants. As the following section indicates, existing law-or lack thereof-renders particularly unsatisfactory the resolution of problems concerning legal parental status in situations involving an unmarried woman and a known donor.

2. Unmarried Women and Known Donors: The Legal Relevance of Pre-Conception Intentions. While the original impetus for artificial insemination (AI) was a desire on the part of the medical profession to help couples who for medical reasons were unable to conceive, AID is also an option for women who desire to reproduce but do not wish to have any sexual involvement with, or a long-term commitment to, a male partner. ${ }^{49}$ Although an increasing number of unmarried women are choosing to create families by means of AID, present statutory law largely ignores this reality. While a few statutes have replaced the phrase "married woman" with the word "woman" in their equivalents of section 5(b) of the UPA,${ }^{50}$ the majority of statutes are silent as to the legal status of the donor in the case of an unmarried woman undergoing AID. Therefore, where the AID legislation does not either implicitly or expressly contemplate AID for unmarried women, or where the factual situation falls outside the conditions described in the legis-

(1987). The non-UPA-based statutes are generally even more skeletal than their UPAbased counterparts.

47. See infra subsection $I(B)(3)$.

48. See infra subsection I(B)(2).

49. According to the survey conducted by the Office of Technology Assessment in 1986-1987, there were approximately 4,000 requests for AID from single women and 1,000 requests from lesbian couples during a 12-month period. ARTIFICIAL INSEMINATION REPORT, stupra note 29 , at 23.

The societal implications of women choosing to have children without marriage are discussed in Carol A. Donovan, The Uniform Parentage Act and Nonmarital Motherhoodby-Choice, 11 N.Y.U. ReV. L. \& Soc. Change 193 (1982-1983).

50. See supra note 40 . 
lation, or where no AID legislation governing parental status exists, the legal paternity of the child is governed by the same family law principles that apply when conception has been achieved by sexual intercourse. Since the application of these principles may lead to a different legal outcome regarding the status of the donor than that intended by the parties, ${ }^{51}$ especially when an unmarried woman and a known donor are involved, present law operates as a significant obstacle in the path of women desiring to use AID with the intent of raising a child in a nontraditional family structure..$^{52}$

The tendency of present AID law to disregard pre-conception intentions when these intentions conflict with the conventional family paradigm is most likely a reflection of society's deep uncertainty as to how the law ought to respond to the deliberate creation of nontraditional family forms through AID, and how it should attempt to balance the respective interests at stake. As a result of the law's apparent ambivalence concerning the social desirability of AID and the law's general tendency to lag behind medical and scientific advances, the issue of legal parental status in AID cases has received minimal legislative attention.

The few reported cases concerning disputes between semen donors and unmarried women demonstrate that courts have not always accorded a great deal of significance to upholding the parties' pre-conception intentions and expectations in determining legal parental status. ${ }^{53}$ Rather, the law treats the unmarried woman and the donor as it would any two biological parents who have conceived a child by natural means out of wedlock. For example, in C.M. v. C.C., decided prior to the enactinent of the New Jersey

51. See infra notes 53-70 and accompanying text.

52. The "traditional" family unit may be described as a married woman and man raising their child or children. Of course, today, divergences from this model are very common, for reasons having nothing to do with AID. High rates of divorce, subsequent remarriages, and out-of-wedlock births mean that many children are being raised in households headed by single women or by stepparents or other adults not biologically related to them. LENORE J. WEITZMAN, The MARRIAGE CONTRACT: SPOUSES, LoverS, AND THE LAW 145 (1981). Whether these nontraditional relationships are viewed legally as "family" relationships has important consequences for adoption, custody, and visitation rights, as well as other areas such as housing, immigration, social security benefits, and private insurance benefits. Some have advocated that the law adopt a functional approach to defining parental status, which would give legal recognition to a broader range of parenting relationships. See supra note 8.

53. See, e.g., Jhordan C. v. Mary K., 224 Cal. Rptr. 530 (Ct. App. 1986); Ex rel. R.C., 775 P.2d 27 (Colo. 1989) (en banc); C.M. v. C.C., 377 A.2d 821 (N.J. Super. 1977); McIntyre v. Crouch, 780 P.2d 239 (Or. Ct. App. 1989), cert. denied, 495 U.S. 905 (1990). 
statute governing AID, the New Jersey Juvenile and Domestic Relations Court held that the semen donor, C.M., was the legal father of a child conceived by AID and had visitation rights and support obligations. ${ }^{54}$ Conflicting evidence was presented as to the parties' understanding of the role that C.M. was to undertake in the child's life. The unmarried woman, C.C., testified that her understanding was that C.M. would be merely a sperm donor and that he would not act as the child's father. C.M., however, stated that he and C.C. had been dating for several months and were contemplating marriage, and that C.M. wished to have a child with C.C. but that C.C. objected to sexual intercourse before marriage. ${ }^{55}$ The court's decision to declare C.M. the child's legal father was based not on an acceptance of C.M.'s version of the facts in preference to C.C.'s, but rather on the court's endorsement of "a policy favoring the requirement that a child be provided with a father as well as a mother." 56 The court held that "C.M.'s consent and active participation in the procedure leading to conception should place upon him the responsibilities of fatherhood."s7 As there was no husband present to assume the role of father, and since the donor in this case was known to the woman, the court held that it was in the child's best interests for C.M. to be declared the legal father.

Essentially, the court in C.M. v. C.C. viewed the case as though the child had been conceived out of wedlock by sexual intercourse. It stated, "If the conception took place by intercourse, there would be no question that the 'donor' would be the father. The issue becomes whether a man is any less a father because he provides the semen by a method different from that normally used." 58

The court's holding that C.M. was the legal father is clear evidence of the aforementioned policy that seeks to promote the nuclear family. ${ }^{59}$ Yet the reason most unmarried women choose to undergo AID is precisely that they do not desire an ongoing

54. C.M., 377 A.2d at 825 . In a subsequent action, C.M. was given the right to have his name listed on the child's birth certificate as the legal father. C.M. v. C.C., 407 A.2d 849, 852 (N.J. Super. 1979).

55. C.M., 377 A.2d at 821 .

56. Id. at 824-25.

57. Id. at 825 .

58. Id. at 824 .

59. See supra notes 17-20 and accompanying text. 
relationship with the biological father of the child. In awarding visitation rights to the donor, the court in C.M. v. C.C. stated, "It is in a child's best interests to have two parents whenever possible." ${ }^{160} \mathrm{Had}$ there been a husband involved who had consented to his wife's artificial insemination, the court would most likely have viewed the husband as the legal father ${ }^{61}$ However, as the inother was an unmarried woman, the court turned to the known donor because "[t]here was no one else who was in a position to take upon hinself the responsibilities of fatherhood when the child was conceived." 62 The court was far inore concerned with providing the child with two parents, one of each sex, than with determining and upholding the parties' pre-conception intent. Yet, there seeins to be little justification for the assumption that it is indeed "in the best interests of the child" to have a biological parent of each sex when those parties may be hostile strangers to each other. ${ }^{63}$

Thus, in the case of an uninarried woman and a known donor who fall outside the protection of a state's AID statute, present law ignores pre-conception intentions and instead treats as paramount the donor's biological connection to the child. Primacy is accorded to biology rather than to intentionality when to do otherwise would challenge conventional societal and legal norms, namely, the nuclear family paradigm.

Legal coinplexities may also result under present law when an agreement exists between the donor and the unmarried woinan that the donor will have legal parental status. While some statutes explicitly provide that such agreements, if in writing, should be upheld ${ }^{64}$ many statutes are silent as to these agreeinents. If a statute severs the legal relationship between the child and the donor when an uninarried woinan is inseminated, and does not provide

60. C.M., 377 A.2d at 825.

61. The court in In re Adoption of Anonymous, 345 N.Y.S.2d 430, 435-36 (Sur. Ct. 1973), did so.

62. C.M., 377 A.2d at 824.

63. See infra Section II(D).

64. Of the states that statutorily sever the legal tie between the donor and the child, only New Jersey, New Mexico, and Washington provide for an agreement between the donor and the woman to the contrary. N.J. STAT. § 9:17-44 (1993); N.M. STAT. ANN. $\S 40-11-6$ (Michie 1994); WASH. REV. CODE $\S 26.26 .050$ (1994). New Hampshire's statute achieves a similar result by providing that an unmarried donor is presumed to be the father of the child if he and the unmarried woman agree to this in writing in advance of the procedure. N.H. REv. STAT. ANN. § 168-B:3(e) (1994); see supra note 45 and accompanying text. 
for any agreement to the contrary, what legal effect-if any-would an agreement have? Put differently, should a person whose legal rights have been divested by statute be permitted to retain those rights by private agreement?

In two cases in which this question has arisen, courts have adopted different approaches. In $E x$ rel. $R . C .,{ }^{65}$ a dispute arose between a known donor and an unmarried woman concerning their pre-conception understanding as to the donor's role following the child's birth. The Supreme Court of Colorado held that the agreement between the parties that the donor would be treated as the father of the child meant that the rights of the donor should be preserved, despite Colorado's adoption of section 5(b) of the UPA ${ }^{66}$ The court concluded that the donor should be treated as the legal father because the Colorado legislature "neither considered nor intended to affect the rights of known donors who gave their semen to unmarried women for use in artificial insemination with the agreement that the donor would be the father of any child so conceived." ${ }^{67}$ However, in McIntyre v. Crouch, ${ }^{68}$ in which a known donor maintained-and the unmarried woman who was inseminated with his sperm denied-that he gave his sperm relying on an agreement that he would remain active in the child's life, the Oregon Court of Appeals held that the state statute severing the donor's legal connection to the child barred the donor "from rights and responsibilities of fatherhood, even if [the unmarried woman] had agreed with him before he gave her his semen that he would have these rights and responsibilities and he gave his semen in reliance on that agreement." on to hold that the statute would violate the Due Process Clause of the Fourteenth Amendment, provided that the donor could establish that he had donated his sperm in reliance on an agreement with the woman that he would have the rights and responsibilities of fatherhood. ${ }^{70}$

\footnotetext{
65. 775 P.2d 27 (Colo. 1989) (en banc).

66. Id. at 33 .

67. Id. at 35 .

68. 780 P.2d 239 (Or. Ct. App. 1989), cert. denied, 495 U.S. 905 (1990).

69. Id. at 243.

70. Id. at 244. Since there was a dispute as to the material facts respecting the existence and nature of the agreement between two parties, the court of appeals held that the circuit court had erred in granting summary judgment to the donor. Id. at 245-46. The case was remanded for a hearing to establish facts that would resolve the dispute.
} 
3. The Impact of Physician Involvement on Parental Rights. In some states, it is currently illegal for AID to be performed by anyone other than a licensed physician. ${ }^{71}$ While this approach is adopted only in a minority of jurisdictions, many state statutes do require that AID be performed "under the supervision of a licensed physician"72 in order for the woman's husband to be recognized as the legal father and that the donor's semen be "provided to a licensed physician"73 before the donor's legal relationship with the child can be severed.

While the absence of a physician causes legal complications in AID situations involving married as well as unmarried women, ${ }^{74}$ the physician requirement poses special difficulties for unmarried women. Many physicians refuse to perform AID when the woman is unmarried, ${ }^{75}$ for a variety of reasons. ${ }^{76}$ Although none of the existing statutes expressly prohibits AID for unmarried women, ${ }^{7}$ the confusion surrounding the legal consequences of AID in this context has operated as a significant deterrent for a large number of physicians. ${ }^{78}$

The reluctance of physicians to perform AID for unmarried women, coupled with the fact that AID is a very simple proce-

71. See supra note 44.

72. UNIF. PARENTAGE ACT § 5(a), 9B U.L.A. at 301 (1987).

73. Id. § 5(b).

74. See McIntyre, 780 P.2d at 243. Arguably, the child would be illegitimate if a married couple conceived by AID without the supervision of a physician, where the statutory provision conferring legitimacy explicitly required physician involvement. See supra note 44.

75. According to a study conducted in 1979 , only about $10 \%$ of physicians performing AI were willing to do so for unmarried women. Martin Curie-Cohen et al., Current Practice of Artificial Insemination by Donor in the United States, 300 NEW ENG. J. MED. 585, 585 (1979). See also ARTIFICIAL INSEMINATION REPORT, supra note 29, at 29. In the 1987 OTA survey, $61 \%$ of physicians indicated that they would reject, for AID, an unmarried applicant who did not have a partner. When a woman was not only unmarried and without a male partner, but also lesbian, the rate of rejection by physicians increased to $63 \%$. Id.

76. These reasons include a belief that children should not be born outside the traditional family unit, a fear that the child will not receive adequate support, and moral or religious objections to AID (which apply whether the woman is married or unmarried). Kritchevsky, supra note 4, at 17.

77. However, the statutes in Connecticut, Kansas, and Oklahoma that limit AID to husbands and wives arguably prohibit the practice for unmarried women. Donovan, supra note 49, at 218-19. Cf. Kritchevsky, supra note 4, at 19 (arguing that statutes that do not mention unmarried women do not prohibit them from practicing AID).

78. Kritchevsky, supra note 4, at 17-18. 
dure, ${ }^{79}$ has led many unmarried women to inseminate themselves using semen obtained either from a sperm bank or from a friend or acquaintance. However, because such semen has not been "provided to a licensed physician" before insemination, the protection offered by the UPA-based statutes in severing the donor's legal rights and responsibilities is not available. Consequently, as a result of the parties bypassing the services of a pliysician, the donor may be declared the legal father over the objections of the unmarried woman. Tlus, women who are deprived of access to AID by physicians and resort consequently to other channels to obtain sperm, thereby place themselves and the donors in a potentially precarious legal situation in the event of a dispute concerning legal parentage.

An example of some of the problems arising in this area is seen in the California case of Jhordan C. v. Mary $K .^{80}$ An unmarried woinan, Mary, decided to conceive by means of AID, witl the intention of raising the resulting child jointly with a close female friend. After interviewing several potential sperm donors, Mary selected Jliordan. At trial, Mary testified that she had not wanted Jlordan to lave ongoing involveinent in the child's life, whereas Jhordan asserted an agreement to the contrary. ${ }^{81}$ The trial court's decision to declare Jhordan the legal father of the child was affirmed by the California Court of Appeal. ${ }^{82}$ The appellate court's decision was based neither on the strength of the evidence as to the parties' respective intentions nor on "any judicial preference toward traditional notions of family structure." ${ }^{\prime 83}$ It was arrived at purely on the ground that the semen used for the insemination had not been obtained from a licensed physician, as required by the California Code. ${ }^{84}$

The court in the Jhordan case acknowledged that "nothing inherent in artificial insemination requires the involvement of a plyysician." ${ }^{85}$ However, the court suggested that there were at

79. Wikler \& Wikler, supra note 1 , at 8.

80. 224 Cal. Rptr. 530 (Ct. App. 1986).

81. Id. at 532

82. Id.

83. Id. at 537.

84. CAL. CIV. CODE $\$ 7005$ (b) (West 1983) states, "The donor of semen provided to a licensed physician for use in artificial insemination of a woman other than the donor's wife is treated in law as if he were not the natural father of a child thereby conceived."

85. Jhordan C., 224 Cal. Rptr. at 535. 
least two justifications that may have motivated the legislature's decision to include the physician requirement: medical screening and the desire to provide a witness who can verify and document that AID has taken place. ${ }^{86}$ While the physician's role in obtaining a medical history of the donor and in conducting medical and genetic screening is an important one, it does not justify denying legal protection to those who have chosen not to avail themselves of physicians' services. There is no reason why sperm banks cannot fulfill this task just as efficiently as physicians. Indeed, a 1987 survey conducted by the Office of Technology Assessment (OTA) indicates that the screening practices of commercial sperm banks appear to be more thorough and comprehensive than those of many physicians. ${ }^{87}$ From a health standpoint, therefore, women

86. Id. at 534-35. An additional advantage, not mentioned by the court, that was historically afforded by the role of a doctor in AID cases was the cloak of "medical therapy" that gave respectability to a practice that was otherwise perceived as morally ambiguous. A distinct moral queasiness is exhibited in the preoccupation of the early caselaw with the questions of whether artificial insemination of a married woman with donor sperm constitutes adultery. See Doornbos v. Doornbos, No. 54 S. 14981 (Superior Conrt, Cook County, Dec. 13, 1954), cited in, Michael J. Yaworsky, Annotation, Rights and Obligations Resulting from Human Artificial Insemination, 83 A.L.R. 4th, 295 310-11 (1991). Cf. People v. Sorensen, 437 P.2d 495, 501 (Cal. 1968) (noting in dicta that artificial insemination of a married woman with donor sperm does not constitute adultery). The clinical setting of physician-performed AID provided an aura of professional legitimacy that helped to dispel, to some extent, any lingering moral uncertainty associated with the notion of a woman being impregnated with the semen of a man to whom she is not married. As has been noted, "[w]ith artificial insemination by donor, medical control converts sin into therapy." Wikler \& Wikler, supra note 1 , at 11. Today, however, questions of adultery and legitimacy have largely been laid to rest, and the notion of AID as " $\sin$ " is not a common one.

87. The OTA survey found that all sperm banks surveyed screened for HIV antibodies, and most screened for a range of sexually transmitted diseases and for specific genetic disorders. ARTIFICIAL INSEMINATION REPORT, supra note 29, at 68-70. The sperm banks generally adopted professional guidelines and procedures as part of their protocols-for example, guidelines set forth by the American Association of Tissue Banks or the American Fertility Society. Id. at 71 . Among the 367 physicians surveyed by the OTA, only $56 \%$ required diagnostic tests other than fertility screening, $44 \%$ tested for the HIV virus, an average of $25 \%$ tested for syphilis, gonorrhea, hepatitis, or chlamydia, and $48 \%$ tested for some genetic disorders. Id. at $34-35$.

The lax screening practices of physicians were documented in an earlier study published in 1979, surveying 379 physicians who performed AID. This survey revealed that family histories taken by physicians were usually limited to superficial questions or a simple checklist of common diseases, that laboratory testing was minimal, and that "[m]ost screening was performed by physicians who were not trained for this task." Curie-Cohen et al., supra note 75 , at 588 .

Currently, only three states-California, Florida, and Indiana-legislatively mandate the screening of semen donors beyond testing to determine HIV status. CAL. HEALTH \& 
undergoing AID may be taking less of a medical risk if they obtain the semen through a sperm bank rather than through a physician who has obtained the semen from a source other than a sperm bank. ${ }^{88}$ Yet the AID legislation in a great many states effectively penalizes parties who choose not to use the services of a physician by affording no legal assurance as to the assignment of paternal rights and duties in that circumstance.

The second justification for physician involvement suggested by the court in Jhordan is that "the presence of a professional third party such as a physician can serve to create a formal, documented structure for the donor-recipient relationship, without which ... misunderstandings between the parties regarding the nature of their relationship and the donor's relationship to the child would be more likely to occur." 89

There is clearly a need to have some mechanism for documenting and verifying the fact that AID has taken place under any legal system in which different legal consequences follow conception through AID as opposed to conception through sexual intercourse. In the absence of a formal mechanism, the only available evidence is the testimony of the parties themselves. This testimony may be of limited usefulness to the court if the parties present inconsistent versions of how conception occurred, in an effort to achieve or avoid particular legal consequences. However, while an objective means of documenting the fact that the conception took place through AID is important in the event of later disputes, this end can be achieved without requiring the presence of a physician. As discussed in Part II, there are alternative means available for recording the fact that AID is being used and for documenting the parties' intentions and expectations regarding parental status. ${ }^{90}$ Moreover, a physician is able to attest that the AID procedure did take place, but is not necessarily able to testify as to the intentions of the parties regarding legal parental status.

SAFETY CODE $\S 1644.5$ (West Supp. 1994); FLA. STAT. ch. 381.6105 (1990); IND. CODE ANN. \& 16-41-14-5 (Burns 1993); see Anita M. Hodgson, The Warranty of Sperm: A Modest Proposal to Increase the Accountability of Sperm Banks and Physicians in the Performance of Artificial Insemination Procedures, 26 IND. L. REV. 357 (1993).

88. Approximately half of the physicians surveyed in the OTA report obtained their donor semen from commercial sperm banks. ARTIFICIAL INSEMINATION REPORT, supra note 29 , at 63 .

89. Jhordan C., 224 Cal. Rptr. at 535.

90. See infra Section II(E). 
The parties may have arrived at an agreement as to the parental roles they envisage for themselves and each other that they have not communicated to the physician.

A third ostensible advantage of physician involvement-not mentioned by the Jhordan court-might be that physicians can maintain medical and personal records concerning the participants in the AID procedure. While record-keeping is important for a number of reasons that have to do with both the physical and the psychological well-being of the child born of AID and the donor, ${ }^{91}$ again there is no reason why this function should be restricted to physicians or why physicians are necessary or particularly well qualified for this task. Indeed, in the vast majority of states the law does not require the inaintenance of records by physicians, ${ }^{92}$ and a large percentage of physicians supervising AID in fact do not keep records. ${ }^{93}$ Many physicians are opposed to any legislative requirement of record-keeping, ${ }^{94}$ probably due to a concern that record-keeping may jeopardize donor anonymity, which in turn may lead to a reduction in the donor pool..$^{95}$ Some

91. For example, a child conceived through AID may have a medical need to access the medical or genetic history of the biological father. Moreover, if the child is born with a genetic disorder or transmissible disease, the physician should be able to contact the donor to inform him of this problem, as well as to ensure that the donor's semen is not used again. Conversely, if a donor discovers a genetic disease later in his life and wishes to convey this information to his AID-born child, the absence of records will make it impossible for him to do so. Further, record-keeping is an important measure in controlling the number of inseminations using any one donor's sperm, thereby minimizing the risk of consanguineous marriages or sexual relationships between AID-born children. Finally, the absence of records deprives the child of the opportunity ever to learn the identity of the child's biological father, a result that could be disturbing to the child. See infra notes 140-43 and accompanying text. While reasonable minds may differ as to the wisdom of disclosing the donor's identity to the child, the failure to keep any identifying information completely forecloses this option.

92. Only two of the non-UPA-based statutes provide for the retaining and filing of the donor's medical records-Indiana and Ohio. IND. CODE ANN. § 16-41-14-14 (Burns 1993); OHIO Rev. CODE ANN. $\S \S 3111.33, .36$ (Baldwin 1992). While the UPA-based statutes provide that the husband's written consent must be certified by the physician and filed with the state, see supra notes 32,34 , there is no requirement that physicians maintain any medical records pertaining to the AID procedure.

93. The Curie-Cohen study of AID physician practices indicates that while $92.2 \%$ of physicians surveyed kept records on the inseminated women, only $30.4 \%$ kept records on donors and only $36.9 \%$ kept permanent records on the children born through AID. $\mathrm{Cu}$ rie-Cohen et al., supra note 75 , at 588 . According to the OTA report, $32 \%$ of physicians surveyed did not keep records. ARTIFICIAL INSEMINATION REPORT, supra note 29, at 46.

94. The Curie-Cohen study found that $82.6 \%$ of physicians opposed any legislative requirement that records on children or donors be maintained. Curie-Cohen et al., supra note 75 , at 588 .

95. Specifically, the fear is that many potential donors may be deterred by the per- 
physicians even deliberately use different donors within the same menstrual cycle to ensure confusion regarding the donor's identity and thus make record-keeping impossible. ${ }^{96}$ Therefore, in light of current physician practice, the requirement of physician involvement can hardly be said to be compelled by the record-keeping function. Moreover, there are others who could equally well perform the task of record-keeping. When a woman obtains sperm from a sperm bank with no physician involvement, the sperm bank could be required to keep records. If a woman selects a known donor and chooses to have no physician involvement, the state could have the responsibility of maintaining confidential records containing identifying information regarding the AID participants. ${ }^{97}$

Thus, making legal parental status contingent on physician involvement is difficult to justify by reference to health concerns, evidentiary considerations, or record-keeping functions. Moreover, the requirement of physician involvement has had a detrimental impact on the autonomy of unmarried women in procreative decisionmaking as to AID. Physicians have assumed a "social gatekeeping" role with respect to AID, making subjective determinations of "fitness for parenthood" under the guise of performing a' "medical" procedure. The social control exercised by physicians in accepting or rejecting AID "patients" is considerable. Physicians apply a wide range of nonmedical standards in determining the suitability of individual women and couples, ${ }^{98}$ sometimes applying criteria that are subjective and idiosyncratic. ${ }^{99}$ In the area of do-

ceived threat of a successful legal action against them with consequent financial obligations owed to the child. See infra notes $156-58$ and accompanying text. The dread of being saddled with legal obligations appears to loom large in the minds of donors, even though the experience of those physicians who do keep permanent records on donors indicates that in reality the threat is extremely remote. George J. Annas, Fathers Anonymous: Beyond the Best Interests of the Sperm Donor, 14 FAM. L.Q. 1, 12 (1980-1981).

96. According to the Curie-Cohen study, $31.8 \%$ of physicians surveyed engaged in this practice. Curie-Cohen et al., supra note 75 , at 587.

97. See infra Section II(E).

98. These criteria include marital status, sexual orientation, age, psychological maturity, financial circumstances, intelligence, educational level, evidence of child abuse, and criminal record. ARTIFICIAL INSEMINATION REPORT, supra note 29, at 27, 29. While commercial sperm banks also employ nonmedical criteria for screening recipients, they are far less likely to reject women on the basis of intelligence. Id. at 65 .

99. Such criteria include, for example, the applicant's honesty, her commitment to keeping the secret of AID from friends and relatives, a reasonable life expectancy, and whether AID is consistent with the applicant's religious faith. See Wikler \& Wikler, supra 
nor selection, too, physicians exercise much social control, frequently applying individualized, social standards in accepting or rejecting donors. ${ }^{100}$

Yet there is little evidence to suggest that physicians have any special training or expertise in this area. Social judgments made by physicians as to eligibility for parenthood for both donors and recipients seriously infringe on the procreative autonomy of women and couples undergoing AID. The legal system has contributed to this problem by creating legal incentives for people to use the services of physicians without ensuring that there is a corresponding inedical advantage, and by allowing physicians to become and remain the self-appointed arbiters of determining parental suitability. Uninarried women desiring AID have been doubly disadvantaged by the physician requirement: first by encountering problems of access to the medical profession, ${ }^{101}$ and then by being denied protection by the legal system when nonmedical alternatives are sought. ${ }^{102}$

\section{A PRoposed INTENT-BASEd LEgAL SYSTEM FOR AID}

Under current AID law, pre-conception intentions are accorded significance only in limited circumstances. When the woman undergoing AID is married, her husband's consent to the AID proce-

note 1 , at $14-15$.

100. Standards used to reject donors include, for example, psychological immaturity, a criminal record, educational achievement below high school level, less than average intelligence, and evidence of child abuse. ARTIFICIAL INSEMINATION REPORT, supra note 29, at 39. These criteria also are employed by commercial sperm banks. Id. at 68 .

Physicians tend to choose an overwhelming percentage of medical students and hospital residents as donors. Curie-Cohen et al., supra note 75 , at 586 . While this is no doubt due partly to reasons of convenience and practicality, physicians may also be engaging to some extent in eugenic decisionmaking. See FINEGOLD, supra note 29, at 37 ("Since we perform insemination using young physicians and upper classmen of the medical school, we assume that our recipients are being fertilized by the spermatozoa of men who are one little step above the average."). As one commentator has observed,

In general [physicians] have chosen to reproduce themselves (or those in their profession), and this is what sociobiologists would probably have predicted. While this should not be surprising, it should be a cause for concern. Physicians may believe that society needs more individuals with the attributes of physicians, but it is unlikely that society as a whole does.

George J. Annas, Artificial Insemination: Beyond the Best Interests of the Donor, 9 hastings Center Rep. 14, 14 (1979).

101. See supra note 75.

102. E.g., Jhordan C. v. Mary K., 224 Cal. Rptr. 530 (Ct. App. 1986). 
dure is required before parental status can be assigned to him. ${ }^{103}$ Therefore, the husband's legal rights and responsibilities with respect to the child born of AID are dependent not only on the existence of a marital relationship between himself and the inseminated woman (as with the common law marital presumption), but also on the existence of his pre-conception intent to assume those rights and responsibilities. ${ }^{104}$

By contrast, when an unmarried woman and a known donor conceive through AID and do not use a physician to facilitate the conception, pre-conception intent is generally not regarded as any more relevant than when two unwed people conceive through sexual intercourse. ${ }^{105}$ This raises the question of whether-when unmarried parties are involved in an AID arrangement-current family law principles should apply, or whether there are reasons that justify departing from that model and applying instead a system of legal rules that takes seriously the parties' pre-conception intent.

\section{A. The Centrality of Pre-Conception Intent in AID}

An important argument in favor of a system based on preconception intentions in AID is that the defining feature of this reproductive technique, when contrasted with coital procreation, is intentionality. Prior to the advent of the new reproductive practices, intentionality played a very limited role in procreation. Historically, while individuals could assert some degree of control in at-

103. See slipra subsection I(B)(1).

104. As noted in the legislative debates on the Illinois Parentage Act, the Act "leaves totally ambiguous a situation of what happens when a married woman is artificially inseminated without the consent of [her] husband." In re Marriage of Adams, 528 N.E.2d 1075, 1089 (IIl. App. Ct. 1988) (Dunn, J., concurring in part and dissenting in part) (citing 83d Ill. Gen. Assem., House Proceedings, Nov. 2, 1983, at 82 (statement of Rep. Brummer)). A question could arise as to whether the common law presumption of legitimacy would operate in an AID case in which the husband had not consented to the AID procedure. While this point has not been addressed directly by the courts, it seems reasonable to infer from existing caselaw that the consent requirement in AID legislation cannot be discarded and replaced by the presumption of legitimacy so as to hold a husband who has not consented to his wife's AID liable for support. See, e.g., Anonymous v. Anonymous, 1991 WL 57753 (N.Y. Sup. Ct. Jan. 18, 1991), in which a husband whose wife was artificially inseminated without his consent successfully sought a judicial declara. tion of nonpaternity. While the court held that he was liable for support payments, this holding was based on a promise he made to his wife after she was already pregnant. Id. at $* 17$.

105. See supra subsection I(B)(2). 
tempting-often through "magical" means-to enhance or diminish the chances for conception, by and large "biological procreation was more a matter of fate than of imtention." 106 Although today much more control is afforded over coital procreation through the use of contraceptives or tests for ovulation, intentions are still often shaped ex post facto as a response to a biological reality, namely, an existing fetus or child. AID, on the other hand, provides considerable opportunity before conception for individuals and couples to exercise a high degree of choice and control over the procreative process and to negotiate the roles they wish to assume in that process. Unlike coital procreation, in which the creation of offspring may or may not be the desired aim of sexual intercourse, AID has the sole aim of reproduction. ${ }^{107}$ This distinction-namely, the centrality of intentionality in AID-demands that the parties' intentions be taken far more seriously than they are in the present, largely biologically based legal model.

\section{B. Respecting the Diverse Intentions of the Woman and the Sperm Donor}

To grant legal parental status to a sperm donor who entered the AID arrangement with no intention of maintaining a committed, ongoing involvement with the child exaggerates the importance of biology to the exclusion of other factors. While biological connection is important, it does not define parenthood. For many, the essence of parenting lies less with biological origins than with the social and emotional relationship associated with the nurturing of a child. A model that makes parenthood entirely contingent on biological connection fails to acknowledge that a biological tie does not necessarily guarantee a social parent-child relationship. ${ }^{10 s}$ A biological connection is not a necessary condition for the development of an ongoing interpersonal relationship between parent and child, nor is it in and of itself a sufficient condition. Moreover, a biological relationship devoid of any commitment to nurturing is inimical to the welfare of the child. More important than biology alone is a commitment to the ongoing care of the child, a commitment that may or may not be grounded in biology.

106. Schultz, supra note 16 , at 304 .

107. Id. at 308-10.

108. Paul Lauritzen, Pursuing Parenthood 82 (1993). 
In the words of one writer, "Parental responsibilities are, in a sense, malienable, but it is not genetic connection that makes them so; rather, it is the intense, person-specific nature of the interpersonal bonds that constitute the parental relation that makes parental responsibility largely nontransferable."109

Furthermore, a system that grants the sperm donor legal parental status merely on the basis of his biological connection to the child ignores a vital distinction between his role and that of the inseminated woman. While both the inseminated woman and the sperm donor have contributed biologically to the creation of the child, the inseminated woman has contributed in an additional way. She has conceived the child not only biologically, but also psychologically. ${ }^{110}$ Without her intention, desire, and efforts in bringing the child into existence, the reproductive process would not have been initiated. ${ }^{111}$ It is the woman, not the sperm donor, who has entered into the AID arrangement with a commitment to the major life task of raising the child. As one writer states,

When the child's existence begins in the minds of the desiring parents, biological conception of the child declines in importance relative to psychological conception with respect to the full life of the child. The mental concept of the child is a controlling factor of its creation, and the originators of that concept merit full credit as conceivers. ${ }^{112}$

In contrast, the genetic father in AID typically sees his role-initially at least-as purely instrumental. Far from being able to claim "full credit as [the mental] conceiver," the sperm donor often makes a decision at the time of insemination that he does not wish to maintain an intense, ongoing social relationship with the child.

These diverse intentions held by the parties upon entering the AID arrangement should be protected by the law. It is most likely that if a woman knew that after conception a potential sperm donor would envisage his role differently from that agreed on, she would not select him as a sperm donor. Similarly, a sperm donor

109. Id. at 83.

110. This process has been termed "mental conception" by one writer. Stumpf, supra note 12 , at $195-96$.

111. John L. Hill, What Does It Mean to Be a "Parent"? The Claims of Biology as the Basis for Parental Rights, 66 N.Y.U. L. REv. 353, 415 (1991).

112. Stumpf, supra note 12, at 195-96. 
would probably not enter into an arrangement if he knew that due to a post-conception change of mind by the inseminated woman, he would be expected to meet certain obligations with respect to the child. Each party relies on representations made by the other, and without those representations the AID process would not proceed.

However, it might be maintained that as far as the sperm donor's promises are concerned, enforcement of his pre-conception intentions is undesirable because it is unknown what emotional changes he may experience either during the woman's pregnancy or at some point after the birth. He may develop an emotional attachment to the child (or prospective child), and consequently may experience profound regret if his rights to the child are alienated. Arguably, the law should protect the sperm donor too from the consequences of his own contractual undertaking, either by holding the contract unenforceable, or by mandating a waiting period after the birth of the child during which the sperm donor may change his mind. ${ }^{113}$ It might further be claimed that in a society that upholds the value of males developing committed relationships with their offspring, it is inconsistent and counterproductive to enforce the donor's original intentions when he has changed his mind and now wishes to take upon himself the responsibilities of fatherhood.

The problem with this line of reasoning is that it undermmes the interest of the woman undergoing AID in being able to plan her familial future with any degree of predictability. Allowing the sperm donor to escape his contractual undertaking violates the woman's autonomy and the choices she has made. There is no obvious reason why the sperm donor's feelings of regret following his change of heart should be accorded greater weight than the feelings of betrayal that the woman is likely to experience in this

113. An analogy may be drawn here with adoption statutes, which in many states do not allow a parent to relinquish parental rights or to surrender a child for adoption until after a specified period following the birth of the child. See, e.g., S.C. CODE ANN. § 20-7-2323 (Law. Co-op 1993). However, this analogy is unsatisfactory because of the asymmetry involved in the comparison between donating gametes, on the one hand, and conceiving, carrying, and giving birth to a child, on the other. The question of whether women who intend to conceive and bear a child for another should be able to relinquish contractually their parental rights prior to the birth of the child has been the subject of extensive debate in the literature relating to surrogacy contracts, e.g., N.J. COMM'N REPORT, supra note 13 , at $141-44$, but is outside the scope of this Article. 
situation. Rather than allowing the woman's autonomy to be compromised, the law should attempt, as far as possible, to minimize the risk of regret on the part of the sperm donor by establishing important safeguards, such as mandatory waiting periods prior to insemination ${ }^{114}$ and mandatory counseling sessions, ${ }^{115}$ designed to ensure that the donor's decision is reached in as thoughtful and fully informed a manner as possible.

A social policy that ignores relied-on representations and expectations consistent with those representations is damaging to the interests of both the inseminated woman and the sperm donor, since it pays inadequate attention to the miportance of safeguarding people's desires to shape their own personal and familial destinies. ${ }^{116}$ In an area as intimate as procreation, it may well be destructive for negotiated expectations to be overridden by a change of intention by one party. As one writer has expressed it, "To ignore the significance of deliberation, purpose and expectation-the capacity to envision and shape the future through intentional choice-is to disregard one of the most distinctive traits that makes us human."117

\section{AID as a Special Case}

If pre-conception intention forms the basis for the proposed legal system governing AID, it might be claimed that identical legal rules ought to govern procreation achieved through sexual intercourse, as long as the parties have agreed on the allocation of parental rights and responsibilities before conception and have clearly documented their agreement. The basis for this claim would be that it is the parties' intentions that are important, not the method by which conception takes place.

As described earlier, the law does not presently allow parties who have procreated through sexual intercourse to negotiate privately their respective legal rights and obligations. ${ }^{118}$ Yet, if an intent-based systein is accepted for AID, some inight argue that it is difficult to see why the same system should not govern sexual intercourse, where the only distinction resides in the instrumentali-

114. See infra note 144 .

115. See infra note 145 .

116. See Schultz, supra note 16 , at $377-78$.

117. Id. at 377.

118. See supra Section I(A). 
ty used to achieve conception. For the state to deny the benefits of the proposed intent-based system on the basis of what many would view as a technicality seems somewhat arbitrary, as well as unduly intrusive. Moreover, since no proof would be available to determine whether the parties in fact conceived by AID rather than sexual intercourse, such a standard would be inherently unenforceable-and for that reason, too, undesirable.

There are, however, two reasons that might justify treating AID as a special case and applying different legal rules for procreation by AID than for procreation by sexual intercourse. The first reason concerns the central role that intentionality plays in AID. As discussed above, while pregnancy may or may not be an intended consequence of sexual intercourse, it is the sole goal of AID. ${ }^{119}$ Although there may indeed be some cases in which parties agree to engage in sexual intercourse specifically and only for the purpose of procreation, in the more usual case there are a number of possible reasons why sexual intercourse takes place. Because of the inherent uncertainty involved in attempting to ascertain parties' motives in sexual intercourse, the law is prepared to impose substantial obligations on males, which cannot be contracted away through private agreement.

Second, whereas in AID the parties contract at arm's length for a commodity (sperm), in sexual intercourse the parties are not necessarily negotiating on equal terms, and objectivity is far more difficult to attain. The psychological and emotional dynamics that may be involved in a sexual relationship are such that a registration system that encompasses conception by this means might open the door to potentially coercive situations, which could be extremely disadvantageous to women. For example, a male might stipulate as a condition of having sexual intercourse with a woman that the two of them first register their "agreement" that the male shall have no parental rights or responsibilities. Thus, if an unintended pregnancy should occur, the child would be the woman's responsibility alone. ${ }^{120}$ While it may be maintained that in such a

119. See supra notes $106-07$ and accompanying text.

120. An alternative scenario could occur in which an unmarried couple has sexual intercourse resulting in an unintended pregnancy, and the male subsequently exerts pressure on the woman to register an "agreement," to avoid his support obligations. However, the establishment of a mandatory waiting period, as proposed in Part III-consisting of several weeks between the time of registration and attempted conception-would resolve this potential problem in a large number of cases. See infra note 144. Moreover, 
case the woman has "consented" to this possibility and that her "choice" must therefore be respected, the potential that exists in sexual imtercourse for an imbalance of power raises troubling questions about the voluntary nature of her consent. ${ }^{121}$

Since one of the purposes of the proposed intent-based system is to allow women-especially unmarried women-to control their own reproductive futures by giving effect to their pre-conception intentions, it would seem inconsistent to establish a registration system that could readily be used in an oppressive manner against women. Moreover, such a system might have the unintended effect of sending an unfortunate message to society regarding male procreational responsibility. Instead of encouraging males to take responsibility for their sexual acts, such a system effectively could release males entirely from any procreational responsibility in connection with sexual imtercourse. In sanctioning a means for men to engage in sexual intercourse without legal consequences, this approach would be deeply destructive to the progress that has been made in conveymg the notion that sexual intercourse carries with it certain responsibilities that cannot be disclaimed at will.

\section{The Interests of the Child}

As discussed earlier, a basic assumption evident in current family law principles is that an arrangement that conforms with the nuclear family model is in the child's best interests. ${ }^{122}$ While there may be much merit in this proposition as a general ideal, it is not necessarily true in the context of AID. It cannot be assumed that a child's needs are always best served by having two biological, legal parents in circumstances in which those parents never originally intended to create a family unit. When the woman's wishes upon entering the AID arrangement were that the sperm donor not have any ongoing involvement in the child's life, or when the sperm donor contributed his sperm with the understanding that he would not be required to contribute financially to

evidence of fraud would vitiate the agreement.

121. See Ruth Colker, Abortion and Dialogue: Pro-Choice, Pro-Life, AND AMERICAN LAW 43-57 (1992) (discussing some of the implications of the coercion and relative powerlessness experienced by many women in sexual relations with men); see also Ruth Colker, Anti-Subordination Above All: Sex, Race and Equal Protection, 61 N.Y.U. L. REv. 1003, 1059 (1986) (proposing the development of laws and policies aimed at eliminating the historical patterns of power inequality between the sexes).

122. See supra notes $12-20,49-63$ and accompanying text. 
help raise the child, the resentment and hostility likely to be experienced by the party whose intentions have been overridden and the probable resulting tensions will hardly be conducive to the child's healthy development. In general, "[h]onoring the plans and expectations of adults who will be responsible for a child's welfare is likely to correlate sigmificantly with positive outcomes for parents and children alike." 123 Although the child may gain some financial advantage if the sperm donor is recognized as the legal father, it is not at all clear that this economic benefit necessarily promotes the best interests of the child. To assert otherwise is to assume both that the amorphous concept of the "best interests of the child" is capable of clear definition, ${ }^{124}$ and that economic benefit must be accorded priority in the hierarchy of values present in the "best imterests" concept. While financial benefit may be one of many relevant considerations, it should not be seen as determinative. When bitterness is experienced either by the sperm donor or by the mother as a result of being forced into a family structure that was neither desired nor intended, any financial benefit to the child that results from this arrangement may not necessarily outweigh or compensate for the potential harm suffered by the child.

But how should an AID parental rights conflict be resolved if the original agreement was that the sperm donor would not contribute financially but it can be shown some years after the birth that the child is in fact suffering economically? Or if the original agreement was that the sperm donor would not have ongoing contact with the child but it is evident at some subsequent point that the child is suffering emotionally or psychologically due to the absence of the biological father, and the sperm donor is available and willing to be involved in the child's life, contrary to the mother's wishes? Should the child's interests be sacrificed in order to uphold the original agreement? One view is that the child's best interests should be the sole guiding principle and the paramount concern. However, to vary the original agreement by according the sperm donor legal parental status over the objections of one of the parties is to ignore relied-on expectations and to remove any element of predictability or certainty from the AID arrangement.

123. Schultz, supra note 16 , at 397 .

124. "Deciding what is best for a child poses a question no less uitimate than the purposes and values of life itself." Mnookin, supra note 26, at 260. 
A possible solution that attempts to take account of the child's interests while still giving weight to intentionality would be to accord a very high presumptive value to the agreement between the sperm donor and the woman, and to allow judicial modification of that agreement over the objections of one of the parties only in exceptional circumstances. For example, when there is strong evidence that the child is suffering emotionally or psychologically, and the sperm donor is available and willing to have some limited contact with the child, the court might revisit the original agreement and decide to grant the child's petition for such contact over the objections of the child's mother. In such circumstances, the donor could be awarded limited visitation rights, but would still not be viewed as the legal father. ${ }^{125}$ It would be important that his rights be carefully and narrowly circumscribed, to avoid undermining the centrality of intentionality. ${ }^{126}$ Particular caution would need to be exercised by courts when the claim is that the child's suffering is financial and that the donor should therefore be obligated to pay support despite a pre-conception agreement to the contrary. Allowing modification of the agreement on this basis could open the door to potential abuses; a woman might fraudulently induce a donor to enter into an AID arrangement by representing that no financial obligations would be incurred on his part, while intending to sue him after conception for support by mvoking the "best interests of the child." Requiring an extremely high standard of evidence in order to overturn the presumed validity of the original agreement would represent an attempt to achieve predictability and certainty of legal outcome, while at the same time providing some flexibility when the court is persuaded that the welfare of the child dictates a modification of the original agreement.

\section{E. Evidence of Intentions: The Role of the State}

In a system in which intentionality would be the primary determmant of legal parental status in AID cases, it would be very important to establish a formal legal structure within which the parties' intentions could be verified and recorded. Given the in-

125. See supra note 9.

126. For example, while he may be granted limited visitation rights, he would not enjoy custodial rights or have support obligations, and the child would not have inheritance rights through him. 
tensely private and personal nature of conception, witnesses are, of course, rarely present at the event; thus, the only evidence of the circumstances surrounding conception and the respective intentions of the parties is the testimony of the immediate participants. The absence of any formal, objective mechanism for ascertaining the nature of the original agreement would make it extremely difficult for a decisionmaker to ascertain what the parties' intentions were, in attempting to resolve post-conception disputes and misunderstandings.

As described earlier, there are a number of reasons why mandating physician involvement in the performance or supervision of the AID procedure is undesirable. ${ }^{127}$ The goal of ascertaining and formalizing the parties' pre-conception intentions and expectations in AID can, however, be achieved without requiring physician involvement. A registration system, whereby parties intending to conceive through AID would be required to register with the State Department of Health, if they wish to enjoy the benefit of a predictable legal outcome, represents one possible solution. ${ }^{128}$

A registration system would offer a number of advantages. First, it would force the parties to clarify their respective intentions and to communicate those intentions to one another prior to the insemination. By placing all parties on notice as to the expectations held, the potential for misunderstandings would be reduced substantially. Second, in the event that a dispute does arise subsequent to the conception, the documents that have been filed would

127. See supra subsection $\mathrm{I}(\mathrm{B})(3)$.

128. Lori B. Andrews, Legal and Ethical Aspects of New Reproductive Technologies, 29 CliniCAL OBSTETRICS \& GYNECOLOGY 190, 199 (1986) (advocating a voluntary registry system). In the case of a known donor, the form would be executed by the woman undergoing AID, her husband (if any), and the donor, and filed with the state. The form would specify clearly that the donor has no legal parental rights or responsibilities, in the absence of an agreement to the contrary between the parties. Any such contrary agreement would be attached to the form, and both documents would be filed with the state. If the woman is married and her husband agrees to be the legal father of the child resulting from AID, he would need to sign and file a form acknowledging his legal paternity. When the known donor acknowledges that he has no legal status vis-à-vis the child but nevertheless expresses his desire prior to conception to maintain some ongoing contact with the child, and when no objection is raised by the woman (or her husband, if any), a "consent to visitation" form should also be signed and filed by the parties.

While legal problems regarding parental status are far less likely to occur in the case of an anonymous donor than with a known donor, the anonymous donor too should be informed in writing of his legal position, and a signed acknowledgment should be filed with the state. 
provide invaluable evidence regarding the parties' pre-conception intentions. Third, a registration system could provide the parties with essential information regarding the legal consequences of their acts. Under the present legal system it is likely that many AID participants-especially in arrangements with known donors-have hittle knowledge concerning their legal positions in the event that one of the parties changes his or her mind post-conception. Finally, for those who choose to register with the state, it would offer an assurance of a legal outcome consistent with their original intentions. For those who use AID without registering with the state, disputes would be resolved by application of current family law principles as they apply to coital procreation.

A registration system would, of course, require a considerable degree of involvement by the state in AID. In addition to having concerns regarding confidentiality ${ }^{129}$ some may argue that it is undesirable for the state to have more than a minimal role in the AID process, given the private, personal nature of the activity in question. According to this view, parties should order their arrangements through private contracts, with the state's role being primarily to facilitate the arrangements by recognizing and enforcing agreements that have been entered into freely. However, while excessive involvement by the state in the reproductive lives of those wishing to procreate through AID is undesirable, a permissive regulatory scheme arguably would have some advantages over a private ordering system. ${ }^{130}$ Through an inducement model ${ }^{131}$

129. The numerous documents evidencing the AID arrangement, for example, may be seen as potentially jeopardizing confidentiality. This concern is a serious one, as lack of confidence in confidentiality could deter many from using a registration system. However, this problem could be overcome through a legislative requirement that all documents filed be kept confidential and sealed, to be inspected only upon court order.

130. A permissive system is preferable to a restrictive regulatory scheme, because the latter would carry with it the danger of intrusive involvement and control by the state. The state might decide, for example, to impose criteria of eligibility for AID that exclude certain groups who have been traditionally disadvantaged and marginalized in procreative matters, such as unmarried women. While this is indeed a matter for concern, it is unclear that any such attempted regulation by the state would withstand constitutional challenge. Arguably, an unmarried woman's right to procreate is a fundamental right protected by the Federal Constitution and, therefore, those provisions in the UPA-based statutes that create obstacles may be unconstitutional if they cannot be justified by a compelling state interest. UNIF. PARENTAGE ACT \$\$ 5, 9B U.L.A. at 301-02, 303 (1987); see Donovan, supra note 49 , at 230 . The right to procreate and the right to privacy, protected by -the Fifth and Fourteenth Amendments to the Constitution, provide the basis for this claim. Griswold v. Connecticut, 381 U.S. 479 (1965). No court has yet ruled on the question of whether access to the new reproductive practices by either married or unmarried 
such as that proposed above, the parties would be assured of a predictable, intended, and desired legal outcome provided certain steps are followed. At the same time, flexibility would be built into the system, as the parties could come to their own arrangement regarding their respective roles vis-à-vis the child, provided their agreement is registered with the state. The state could thereby maintain a degree of control over the process, enabling it to play a constructive role in addressing comprehensively the many important aspects of the practice of AID that require legislative attention. ${ }^{132}$

\section{BIOLOGY AND PROCREATIONAL RESPONSIBILITY IN AID}

If an intent-based system as proposed above is adopted, does it follow that the donor's contribution of sperm should be regarded as "merely" biological and therefore of little, if any, legal consequence in all contexts? Specifically, even if the donor does not acquire legal parental status, might the fact that he has donated sperm impose on him certain legal obligations concerning the disclosure of his identity at some future point to his biological child?

It inight be contended that under a system based on intentionality, the biological contribution of the donor should be considered to be relatively unimportant. This argument is grounded in the assumption that intentionality and biology are essentially dichotomous, so that any attempt to give weight to both factors results in

persons is a fundamental constitutional right. For an analysis of the constitutional implications involved in the use of the new reproductive practices by unmarried persons, see Donovan, supra note 49, at 216-22; Kritchevsky, supra note 4, at 26-40; Denise S. Kaiser, Note, Artificial Insemination: Donor Rights in Situations Involving Unmarried Recipients, 26 J. FAM. L. 793, 802-07 (1987-1988); Patricia A. Kern \& Kathleen M. Ridolfi, Note, The Fourteenth Amendment's Protection of a Woman's Right to Be a Single Parent Through Artificial Insemination by Donor, 7 WOMEN's RTS. L. REP. 251, 258-70 (1982); Note, supra note 4, at 677 .

131. See supra note 35 .

132. These include, for example, the medical screening of sperm donors by physicians and sperm banks, and the maintenance of records containing information regarding the personal, medical, and genetic histories of AID participants. In addition, the number of children conceived using any one donor's sperm could be strictly limited, to avoid potential problems of incest between children born of AID. This would require accurate records on donations to be maintained by physicians and sperm banks on a centralized computer registry, to prevent the possibility of a donor making multiple donations at different locations. Stringent measures would need to be' adopted to ensure that only authorized personnel have access to the stored information relating to the identity of those participating in an AID arrangement. 
irreconcilable tension. In actuality, both intentionality and biology are significant, but they are significant in different contexts. Emphasizing only intentionality or only biological contribution leads to a partial, and therefore distorted, perspective. While this Article proposes that pre-conception intentions should govern the determination of legal parental status, it also maintains that there needs to be a collective recognition, reflected in our legal system, that donating genetic material is an act with important personal, moral, and societal implications. Such a recognition might lead to the imposition of specific legal obligations on the donor, even when the donor is not accorded legal parental status.

Due perhaps to the rapid medicalization of AID and the consequent legitimation of the practice, AID became accepted with relatively little public debate concerning its possible psychological and emotional impact on both the donor and the child. Moreover, as sperm banks have become widely established, ${ }^{133}$ scant attention has been paid to the social and moral desirability of encouraging males to father children anonymously. The interest of the medical profession in creating and maintaining a large and constant pool of donors has led to a view of AID-largely unchallenged to this day-as a health issue, rather than as an issue with potentially profound personal and societal ramifications. ${ }^{134}$ Since the principal purpose of sperm banks always has been to help infertile couples, sperm donation generally has been socially encouraged and even applauded. Many view sperm donation in much the same light as blood donation, and indeed there are some obvious parallels. ${ }^{135}$ Both sperm and blood are products of the body, donated

133. Terra Ziporyn, "Artificial" Human Reproduction Poses Medical, Social Concerns, 255 JAMA 13, 13 (1986) (noting that there were "about 25 commercial and universitybased sperm banks in the United States" in 1986).

134. Daniel Callahan, Opening the Debate?: A Response to the Wiklers, 69 MILBANK Q. 41, 43 (1991).

135. However, sperm "donors" are usually paid for their contributions, unlike most blood donors. A more accurate appellation would be "sperm vendor." Sperm "donors" generally receive $\$ 25$ to $\$ 50$ per donation. John A. Robertson, Technology and Motherhood: Legal and Ethical Issues in Httman Egg Donation, 39 CASE W. RES. L. REV. 1, 29 (1988-1989). While a detailed discussion of the issue of payment for sperm lies beyond the scope of this Article, a legal system that aims to convey the profound personal and societal implications of gamete donation ought to consider whether the commercial exchange of gametes is desirable. The fact that gametes have life-creating potential and that they bear unique genetic characteristics means that it may be inappropriate to trade them as "commodities" in the market. As one writer has noted, "If certain human parts are 'dignified,' then our social traditions suggest they may be given, but not sold, and owner- 
to people in need. Both are easily accessible, involving no intrusive or dangerous surgical intervention. Both are substances that are painlessly and quickly replenished by the human body. However, these similarities should not obscure one critically important distinction between sperm donation and blood donation: while blood is life-sustaining, sperm is life-creating. Blood supports hife, but sperm is used to create a new and unique genetic identity, a human being. Given the life-generating quality of sperm donation, how should society view this activity?

On a societal level, it can be argued, the sanctioning of biological fatherhood with absolutely "no strings attached"-a description that applies to the current practice of artificial insemination using an anonymous donor's sperm-sends entirely the wrong message regarding male procreational responsibility. While inany-including, of course, numerous feminists-have long attempted to encourage inales to appreciate that they bear some responsibility for the lives of the children they beget, the cavalier inanner in which society has treated sperm donation directly undermines this message. As Daniel Callahan asks, "[W] hat is AI other than an organized and sanctioned way of allowing men to be biological fathers and still bear no responsibility for their children?"136

On a personal level, the current practice of anonymous sperm donation may have a variety of possible negative effects on the well-being of both the sperm donor and the child. The sperm donor inay suffer as a result of the lack of information concerning any child he nray have begotten-or indeed, even as to whether or not a live birth has resulted. He may also suffer froin the knowledge that he will never have the opportunity to nieet his biological

ship of them is only of a special, limited kind." Thomas H. Murray, Gifts of the Body and the Needs of Strangers, 17 HASTINGS CENTER REP. 30, 38 (1987).

Payment beyond direct expenses should be prohibited for both sperm and egg donors, and contracts involving payment should be held void as contravening public policy. Resolution of parental rights disputes arising from such agreements would thus be governed by traditional family law principles. While this approach would constitute a limitation on the proposed intent-based model, its impact on sperm donation would be relatively slight compared with its effect on egg donation. The considerably greater payments involved in egg donation (usually $\$ 1,500$ to $\$ 2,000$ ), combined with the fact that, unlike sperm donation, egg donation constitutes an invasive medical procedure with attendant risks to the donor, mean that payment to egg donors can create an inducement that is potentially coercive. For a discussion of the issue of payment to egg donors, see Robertson, supra, at 29-33.

136. Callahan, supra note 134 , at 43. 
child. Typically, sperm donors are young men who donate before they have started their own families. ${ }^{137}$ At this stage in their lives, they may have given little serious thought to the emotional complexities sometimes involved in sperm donation-complexities that may arise only decades later. Counseling is not offered routinely at sperm banks, ${ }^{138}$ and consequently many donors may not have considered fully the implications of their actions. It is not surprising, therefore, that "[1]ater on when they have children of their own ... some sperm donors experience remorse about the artificial insemination children they may have created who are out there in the world, might be in need, and cannot be contacted." 139

Long-term anonymity in sperm donation may have especially serious negative effects on children born of AID. The importance of preserving the opportunity for children to trace their biological origins has been well documented in the adoption context. ${ }^{140}$ Recognition of the strong psychological need experienced by many adoptees to identify their biological parents has led a number of courts to allow children access to sealed adoption records. ${ }^{141}$ The "genealogical bewilderment" that can result from being deprived of a part or all of one's genetic heritage can lead, in some cases, to a serious identity crisis. ${ }^{142}$ While it may be claimed that the psychological burden of adoptees is greater than that of children born of AID, given that children born of AID at least have access to one half of their ancestry, denying children born of AID knowledge of one biological parent nevertheless may undermine their sense of identity. As noted earlier, in addition to the psychological need to search for their origins, children born of AID might also have an

137. Ziporyn, supra note 133, at 14 (noting that "[m]ost sperm donors . . . have not started their own families. ... The average age [of a donor] is 23." (quoting Lori Andrews, medical law and research attorney, American Bar Foundation)).

138. See Robert D. Nachtigall, Secrecy: An Unresolved Issue in the Practice of Donor Insemination, 168 AM. J. OBSTETRICS \& GYNECOLOGY 1846, 1851 (1993) (arguing that counseling should be available to sperm donors).

139. Ziporyn, supra note 133, at 14 (quoting Lori Andrews, medical law and research attorney, American Bar Foundation).

140. See generally ARTHUR D. Sorosky ET AL., THE Adoption Triangle (1978) (documenting the negative effects of sealed adoption records).

141. For examples of cases in which the adopted child's interest in knowing the identity of his or her biological parent has received legal recognition, see Lucinda Ann Smith, Artificial Insemination: Disclosure Issues, 11 COLUM. HUM. RTs. L. REV. 87, 90 n.25 (1979).

142. See SOROSKY ET AL., supra note 140, at 113. 
important interest in learning their full medical histories, particularly as to hereditary characteristics. ${ }^{143}$

While a number of safeguards, such as mandatory waiting periods ${ }^{144}$ and counseling, ${ }^{145}$ could be established to minimize the possible harmful psychological and emotional effects of anonymous donation for both the donor and the child born of AID, the most important step that needs to be taken involves a critical reexamination of the current system of long-term anonymity for donors. To many, anonymity in AID is a sacrosanct principle, and any inroad into it is highly objectionable. ${ }^{146}$ Historically, anonymity has been regarded as essential in ensuring a constant and plentiful supply of sperm. The fear has been that any threat to guaranteed long-term anonymity would deter prospective donors, resulting in depleted resources. However, two questions need to be asked in this context: first, how much weight should be given to donors' rights to privacy, as against children's rights to trace their biological heritage? Second, how realistic is the fear that donors

\section{See supra note 91 .}

144. The main purpose of a mandatory waiting period between registration and insemination would be to give prospective douors the opportunity to reflect on whether sperm donation is desirable for them, thereby minimizing the possibility of precipitous decisions by douors. A waiting period might also assist in conveying the message to potential donors that donating sperm is a decision to be considered seriously, not one to be made hastily. An additional advantage of a waiting period-at least, if it is several weeks in duration-is that it may protect against fraud, such as when parties attempt to register post-conception following sexual intercourse.

The purpose of a waiting period as suggested here should be distinguished from the purpose of a waiting period in the context of abortion. The subject of waiting periods in abortion has been extremely controversial, because in that context waiting periods impose a substantial obstacle for many women seeking an abortion. See RUTH COLKER, Pregnant Men: Practice, Theory and THE LaW 89-127 (1994). However, in the AID context, the waiting period is directed toward the sperm donors rather than the women, and its purpose is to provide accurate information to the donor so that he can make an informed decision, thereby minimizing the risk of potential misuuderstandings or later regrets.

145. Sperm banks and physicians could offer counseling sessions-mandatory for firsttime donors-to each prospective donor, aimed at increasing the donor's awareness of the emotional consequences that may ensue as a result of the sperm donation, so that he is able to make a fully informed decision as to whether he wishes to donate. Arguably, it is only then that the donor could truly give his "informed consent" to the sperm donation. Further, all donors should be informed when a live birth results from the use of their sperm, so that they have no uncertainty as to whether they did or did not beget a child or children.

146. See, e.g., Smith, supra note 141, at 97 (arguing that "the identity of the sperm donor should not be disclosed"). 
would be deterred from donating if long-term anonymity were not guaranteed?

While donors' privacy interest until now has been scrupulously safeguarded both by physicians and by sperm banks, it is not at all self-evident that this imterest should necessarily outweigh children's interest in knowing their biological fathers' identities. As noted earlier, children may have compelling needs relating to "genealogical bewilderment" suffered as a result of being denied access to one half of their biological heritage.$^{147}$ Moreover, the donor has a choice as to whether he wishes to enter the AID arrangement: if his interest $\mathrm{m}$ maintaining his privacy outweighs his desire to be a donor, he decides accordingly. The child, on the other hand, has no choice regarding the arrangements made between the adult participants, arrangements that may affect the child's life profoundly. Given the child's relative powerlessness, and the potentially damaging consequences that anonymous fatherhood might have on the child's development, it seems that the law may have been protecting the donor's interests at the expense of the child's for too long. ${ }^{148}$ The current system fails to recognize any responsibility on the part of the anonymous donor and ignores the profound impact that the donor's act can have on the child. Callahan accurately describes the present system of anonymous donation in the following terms:

As a symbol of male irresponsibility -and a socially sanctioned symbol at that-one could hardly ask for anything better than artificial insemination with the sperm of anonymous donors. It raises male irresponsibility to the high level of a praised social mstitution, and it succeeds in getting males off the hook of fatherhood and parenthood in a strikingly effective and decisive way. ${ }^{149}$

The adoption experience has shed much light on the inportance placed by many children on being able to trace their biological heritage. Just as in many states adopted children are allowed access to their sealed records when they have reached the age of majority ${ }^{150}$ or provided they can show good cause, ${ }^{151}$ children

147. See supra notes $140-43$ and accompanying text.

148. Annas, supra note 95 , at 11-12.

149. Daniel Callahan, Bioethics and Fatherhood, 1992 UTAH L. REV. 735, 741.

150. See, e.g., KAN. STAT. ANN. § 65-2423 (1993).

151. See, e.g., N.Y. DOM. REL. LAW \& 114 (McKinney 1994). 
born of AID too ought to be granted access if the need is similarly compelling. Donors, therefore, should be informed prior to the time of donation that any child resulting from the AID process (regardless of whether the mother is married or unmarried at the time the donation is made) may be entitled at a certain point later to contact the donor. ${ }^{152}$ The donor would, of course, have no rights or financial obligations with respect to the child at that point or at any other time. However, he should understand before agreeing to donate that his anonymity is guaranteed not absolutely, but only insofar as it does not infringe on the child's compelling need to discover his identity. It should also be made very clear to the donor before he donates that any such contact may be initiated only by the child, not by the donor. ${ }^{153}$

Procreation by means of sperm donation ought to entail some minimal level of responsibility, even though the donor may have no intention of being the rearing parent. Far greater thought needs to be given to the effects that anonymous donation may have on the child, the donor, and the family. ${ }^{154}$ As one child born of AID, Suzanne Rubin, has stated poignantly,

I hope that any man who is thinking of being a sperm donor will stop and consider the possibility that twenty years from now your child will confront you and want to know what kind of human being you are, and why you found it so easy to sell the essence of life to a total stranger. ${ }^{155}$

152. The relevant age of the child could be set, for example, at the age of majority, as it is in many adoption statutes. Alternatively, a more flexible standard could be employed whereby an individualized assessment is made in each case taking into account the child's needs and maturity; for example, in Sweden, legislation grants a child born of AID access to identifying information when the child has reached "enough maturity," as determined by the hospital and a social worker. See infra note 158 .

153. Allowing the donor to initiate contact would be undesirable, as it might prevent the development of a stable relationship between the legal parent or parents and the child and thereby threaten the security and integrity of the child's family unit.

154. See generally ANNETTE BARAN \& REUBEN PANNOR, LeTHAL SECRETS 167-75 (1989) (documenting the destrnctive impact of secrecy in AID); R. SNOWDEN ET AL., ARTIFICIAL REPRODUCTION: A SOCIAL INVESTIGATION 166-82 (1983) (describing the social implications of AID); Ken R. Daniels \& Karyn Taylor, Secrecy and Openness in Donor Insemination, POL. \& LIFE SCI., Aug. 1993, at 155.

155. Chris Clayton, The Rights of the Natural Father: AID Donor, in Changing FamILIES: PRoceEdings of THE THIRd Australian Conference on AdOPTION 65 (R. Oxenberry ed., 1982). 
The concern that lack of long-term anonymity would discourage sperm donors from donating may be realistic under the present legal system governing parental legal status in the context of AID, but would be far less likely to be so under the proposed intent-based system. Given that the current system is largely biologically based rather than intent-based, it is little wonder that the fear of potential legal complications looms large in the minds of donors and is likely to operate as a strong disincentive to entering into an AID arrangement, unless there exists a promise of anonymity. However, this fear would quickly dissipate under an intent-based legal system in which the donor would incur no legal obligations unless he and the woman have expressly agreed to the contrary, prior to the insemination. Anonymity for the sake of protecting the donor from legal obligations would, therefore, be an unnecessary measure. ${ }^{156}$

Of course, even if the threat of legal obstacles were removed, some donors might be reluctant to donate without long-term anonymity because they might fear that their privacy would be invaded by their AID-born offspring at some future point, causing possible disruption in their personal lives. However, there are data to suggest that "although concerned and wary, donors are not as desperate about having absolutely no contact with the child and about having no information about them relayed to the [recipient] family as was previously thought." ${ }^{157}$ Since not all donors find the

156. It is also important to note that not all donors are influenced by the possibility of legal complications. Some recent studies indicate that even under the present system in which the threat of legal complications is significant, there is a subgroup of donors who would be prepared to donate without the assurance of anonymity. See infra note 157 .

157. Robyn Rowland, The Social and Psychological Consequences of Secrecy in Artificial Insemination by Donor (AID) Programmes, 21 SOC. SCI. MED. 391, 394 (1985). In a survey of donor attitudes in Australia, Rowland found that $82 \%$ of donors surveyed did not object to the giving of nonidentifying information to the couple, $46 \%$ indicated that they would like nonidentifying information to be kept, $46 \%$ stated that records including identifying information should be maintained, $42 \%$ said they would donate even if their names were made available to recipients, and $60 \%$ of donors stated that they would not mind if their AID-born offspring, after reaching the age of 18 , contacted them in order to discuss their family background. Id. at 395 .

In the United States, a 1981 survey of 39 donors contributing to sperm banks in the Los Angeles area found that $49 \%$ of the donors thought children born of AID should have the right to discover their biological parents. Linda S. Fidell et al., Paternity by Proxy, in GENDER IN TRANSITION 93-110 (Joan Offerman-Zuckerberg ed., 1989). When asked whether they thought donors had any responsibility toward AID children, $21 \%$ said "yes." Id. at 101 . The most commonly agreed on responsibility was to report 
idea of identifying information being maintained, or even the possibility of being contacted by the child in the future, objectionable, it is unclear to what degree the size of the donor pool would be affected. ${ }^{158}$ Moreover, it could be argued that even if there were some cost in the form of a reduction of the number of available donors, it might be preferable-both from an individual and from a societal point of view-to accept fewer donors, but donors of a different type: namely, donors who do not just donate their genetic materials for financial gain, but who have given serious thought to the complicated psychological and emotional implications of AID and who are prepared to take some responsibility for their involvement in the process.

\section{CONCLUSION}

A fresh legal blueprint is required if the "new" reproductive technique of AID is to be suitably assimilated into the legal system. Since family law principles that apply to procreation through sexual intercourse are not necessarily transferable to AID, state

any potentially inheritable health problems that appeared after donation. Thirty-six percent said they would like to meet their biological children. Only 5\% said they thought a donor should have access to his AID-born child, and $13 \%$ said they would be bothered by meeting an AID-born child who bore a striking resemblance to themselves. Id. at 102 . The authors note that there was "some evidence that donors did not take their donations lightly" and that it "appears that [donors] felt greater responsibility toward AID children than the public feels they have." Id.

The willingness of many donors to be contacted by their adult AID-born offspring is reported also by the Sperm Bank of California in Oakland. Judith Gaynes, A Scandal of Artificial Insemination, N.Y. TIMES, Oct. 7, 1990 \& 6 (Magazine), at 23. This sperm bank requires each donor to sign a contract either allowing nonidentifying medical records to be made available to recipients, or expressly permitting the donor's name and address to be released to his biological child, provided the child is 18 years of age and has requested the information. According to the director of the sperm bank, more than half of the donors choose to provide identifying information. Id.

158. There is little empirical data available outside the United States regarding the effects of disclosure of identifying information on donor supply, because most countries do not allow identifying information to be revealed. However, Sweden has enacted legislation that grants AID-born children who have reached "enough maturity" the right to learn the identity of their biological fathers, and to contact them. Swedish Law, No. 1140/1984, cited in Daniels \& Taylor, supra note 154, at 166. Initially it was feared that this legislation would deter potential donors. However, according to one commentator, "[T]his fear has not been realized. The initial response was exactly as predicted: current donors stopped donating. But within months the number of donors had risen again to previous levels, and reports indicate that a different kind of donor is becoming involved in programs." Rona Achilles, Donor Insemination: The Future of a Public Secret, in THE FUTURE OF HUMAN REPRODUCTION 105, 115 (Christine Overall ed., 1989). 
legislation to resolve the difficult parental rights conflicts that inevitably arise in AID needs to be enacted.

An intent-based legal model, in which the pre-conception intentions of the parties would form the critical determinant in assigning legal parental status, would be a significant step in the resolution of conflicts in this area. Under this system, parties would be able to structure their affairs to achieve the legal consequences they desire, by registering their agreement with the state prior to carryimg out an AID procedure. When a conflict arises because one party has changed his or her mind, the dispute would then be resolved according to the terms of the original agreement. Should the court be persuaded that enforcing the pre-conception agreement would be contrary to the welfare of the child, it would have the option of reviewing the original agreement and modifying its terms. While this power should be exercised very sparingly so that the intent-based system is not undermined, it would provide some needed flexibility.

The law's response to the new reproductive practices to date has generally been reactive rather than proactive. Too often the legal approach in this area has been one of "crisis management," in which laws are formulated in response to specific fact situations that require speedy resolution. This path has failed to acknowledge that what is required is a paradigmatic shift in legal thinking. What is needed today is a coherent legal framework that is comprehensive in scope and sensitive to the ethical and societal impact of this new reproductive era. 